\title{
China's Stance on Investor-State Dispute Settlement: Evolution, Challenges, and Reform Options
}

\author{
Yuwen $\mathrm{Li}^{1} \cdot$ Cheng Bian²
}

Accepted: 10 November 2020 / Published online: 15 December 2020

(c) The Author(s) 2020

\begin{abstract}
China is one of the most active states in concluding bilateral investment treaties (BITs) globally. Its BITs can be categorized into three generations based on the homogeneity of the investor-state dispute settlement (ISDS) provisions within each generation. The China-EU Comprehensive Agreement on Investment and the China-US BIT under negotiation are expected to inaugurate a fourth generation, although China's stance on ISDS in both treaties remains indeterminate. This article elaborates on the distinctive characteristics of ISDS provisions by mapping three generations of Chinese BITs, presenting the challenges that these ISDS provisions have brought to light in investor-state adjudication as well as in the context of the Belt and Road Initiative, and expounding on China's policy options in ISDS reform. The on-going intense debate on ISDS reform presents China with an opportunity to shift from its traditional role of a rule-taker to a rule-maker in redesigning the ISDS mechanism. However, China's current policy and practice do not demonstrate an ambition for such a transformation. Looking forward, it may well be in China's long-term interest to endorse a Multilateral Investment Court as vigorously advocated by the EU.
\end{abstract}

Keywords Belt and Road Initiative · China-EU CAI · China-US BIT · Chinese bilateral investment treaties · International investment law $\cdot$ Investor-state dispute settlement $\cdot$ Multilateral Investment Court

Yuwen Li

y.li@law.eur.nl

Cheng Bian

bian@law.eur.nl

1 Professor of Chinese Law, Director of Erasmus China Law Centre, Erasmus School of Law, Erasmus University Rotterdam, Rotterdam, The Netherlands

2 Academic Researcher, Erasmus China Law Centre, Erasmus School of Law, Erasmus University Rotterdam, Rotterdam, The Netherlands 


\section{Introduction}

The conclusion of bilateral investment treaties (BITs) on the global scale has been one of the most dynamic fields of international investment law during the past few decades. Starting with the first BIT signed between West Germany and Pakistan in 1959, there have been 2897 BITs and 390 treaties with investment provisions concluded globally by May 2020. ${ }^{1}$ The proliferation of BITs worldwide is driven by some of the most active signatory countries, among which China plays a significant role. Since it signed the first BIT with Sweden in 1982, China has signed 138 BITs, and 126 of them are currently in force, second only to Germany in terms of the number of BITs concluded. In addition, China has concluded one trilateral investment agreement with Japan and South Korea in 2012 and 13 free trade agreements (FTAs) containing investment provisions. ${ }^{2}$

Chinese BITs can be distinguished into three generations in terms of their different levels of substantive protection and their disparate characteristics of investorstate dispute settlement (ISDS) provisions. ${ }^{3}$ The ISDS mechanism has always been

${ }_{1}$ UNCTAD, Investment Policy Hub, International Investment Agreements Navigator, available at: https
://investmentpolicyhub.unctad.org/IIA (accessed 23 September 2020).
${ }^{2}$ Specifically, China has entered into FTAs with Chile (2005) (renegotiated in 2017), Pakistan (2006), New Zealand (2008), Singapore (2008) (renegotiated in 2018), Peru (2009), ASEAN (2009) (renegotiated in 2015), Costa Rica (2010), Iceland (2013), Switzerland (2013), South Korea (2015), Australia (2015), Georgia (2017), and Maldives (2017). Some of these FTAs do not contain investment provisions (e.g., the China-Georgia FTA). Some only provide a general framework for the promotion of investment without viable investment protection provisions (e.g., the China-Switzerland FTA). Some incorporate the text of previously negotiated BITs between China and the same signatory state as an integral part of the investment provisions in the FTA (e.g., the China-Costa Rica FTA). And there are FTAs that include a comprehensive or updated investment chapter, where investment topics are extensively addressed next to trade, including the China-New Zealand FTA (2008), the China-ASEAN Agreement (2009), the ChinaSouth Korea FTA (2015) and the China-Australia FTA (2015). Based on the modality in which such investment chapters are stipulated, the ISDS mechanism in the China-New Zealand FTA (2008) in its essence is equivalent to the ISDS in second generation Chinese BITs, whereas the China-ASEAN Investment Agreement (2009), the China-South Korea FTA (2015) and the China-Australia FTA (2015) are in accordance with the ISDS in third generation Chinese BITs. Due to the limited scope of this research, China's FTAs with investment provisions will not be further discussed. China FTA Network, China's Free Trade Agreements, available at: http://fta.mofcom.gov.cn/english/fta_qianshu.shtml (accessed 23 September 2020).

3 In principle, Chinese BITs are divided into either three or four generations, and the time span for each generation is defined differently by various scholars. For instance, Congyan Cai has divided Chinese BITs into three generations, namely the Conservative Paradigm (1982-1998); the Liberal Paradigm (1998-2005); and the Balanced Paradigm (2006-). See Cai (2009), pp. 461-462.

Manjiao Chi opines that the first generation includes BITs concluded before the late 1990s, the second generation includes BITs concluded after the late 1990s and before the 2010s, and the third generation includes BITs concluded after the 2010s. See Chi (2017), p. 163.

Axel Berger has divided Chinese BITs into four generations. The first phase was from 1982 until the end of the 1980s. The second phase was from the early 1990s to the late 1990s. The third phase was from 1998 to 2008. And the fourth phase started from 2008 up until today. See Berger (2015), pp. 844-845.

Matthew Levine divides Chinese international investment agreements (IIAs) into four generations. First generation of IIAs was concluded from 1982 to 1989 with developed and capital-exporting states, containing narrow dispute settlement clauses. Second generation of IIAs was concluded from 1989 until the late 1990s, which retains continuity with the first generation but was negotiated with developing states. Third generation of IIAs was concluded with both developed and developing states that includes rela- 
a salient component of Chinese BITs. In this article, we define three generations of Chinese BITs based on the scope of consent to arbitration in ISDS provisions. The first generation Chinese BITs were signed from 1982 to 1999 (see Appendix Table 2), during which period China concluded BITs both with capital-exporting developed countries to attract inward foreign direct investment (FDI), and with capital-importing developing countries to promote China's outward FDI. These BITs provide either no ISDS provisions at all or a narrowly constructed ISDS clause that only admits 'the amount of compensation for expropriation' to arbitration. ISDS provisions in second generation Chinese BITs signed from 1997 to 2011 (see Appendix Table 3) are characterized by the abandonment of restricted admissibility in the previous generation and instead allow for the admission of legal disputes, or disputes in connection with an investment, or a combination of both, to arbitration. Calibrated to strike a balance between investment protection and the host state's right to regulate, third generation Chinese BITs since 2007 (see Appendix Table 4) incorporate ISDS provisions that admit disputes where an investor or its investment has incurred loss or damage by reason of or arising from breaches of specific treaty obligations that are explicitly enumerated.

The evolutional trajectory of Chinese BITs creates several challenges. First, the complexity and diversity of the ISDS provisions in three generations of Chinese BITs result in the fragmentation of ISDS provisions. Further, the linguistic ambiguity of ISDS provisions has created inconsistency in investment dispute adjudication. For instance, while first generation Chinese BITs only admit 'the amount of compensation for expropriation' for arbitration, inconsistent interpretations of identical clauses based on different interpretative techniques and opposite decisions have been adopted by four arbitral tribunals and two national courts. ${ }^{4}$ Third, in the context of the Belt and Road Initiative (BRI), Chinese investors and their outbound investment may suffer from a lack of access, or insufficient access to the ISDS mechanism due to the fact that the majority of BRI countries have either no BITs or first generation BITs with China.

In recent years, China has been active in modernizing its BIT regime. China is in the process of negotiating a BIT with the EU and the US respectively, which is expected to inaugurate a fourth generation of BITs once they are concluded. Further, China has upgraded its BIT regime on a case-by-case basis by adopting four different models, and has actively promoted Chinese institutions to resolve investorstate disputes. China is also an active participant in the ongoing discussion on ISDS reform under the auspices of the United Nations Commission on International Trade Law Working Group III (UNCITRAL WG III), by proposing a multilateral appeal

\footnotetext{
Footnote 3 (continued)

tively broad dispute settlement clauses and guarantees of national treatment from the late 1990s to 2008. And fourth generation of IIAs began in 2008 which emphasizes regionalization, the conclusion of preferential trade and investment agreements, and interpretative and substantive balancing mechanisms in the investment treaty provisions. See Levine (2019).

${ }^{4}$ For a detailed discussion of these cases, see infra Sect. 2.
} 
mechanism. These efforts and measures, however, may come with various limitations, shortcomings, and trade-offs.

The purpose of this article is to elaborate on the commonalities and disparities of ISDS provisions by mapping three generations of Chinese BITs, presenting the challenges that ISDS provisions have brought to light in investor-state adjudication as well as in the context of the BRI, and expounding on China's policy options in ISDS reform. After this introductory section this article proceeds as follows. Section 2 discusses ISDS in first generation Chinese BITs, including a comprehensive examination of these ISDS provisions concerning their contracting states, amicable settlement, admissible disputes, the venue of arbitration, the exhaustion of local remedies, the fork-in-the-road provision, and the governing laws. Following the same structure and purpose as Sect. 2. Sects. 3 and 4 discuss the ISDS provisions in second and third generation Chinese BITs respectively. Section 5 examines the ongoing China-EU Comprehensive Agreement on Investment (CAI) and the China-US BIT negotiations as an emerging fourth generation Chinese BIT in the making. Section 6 discusses two approaches China has adopted to facilitate dispute resolution in the BRI, as well as their respective shortfalls and limitations. Section 7 explores the possible options that China may choose in ISDS reform in the future, including China's position at the UNCITRAL WG III. A conclusion is provided in Sect. 8.

\section{ISDS in First Generation Chinese BITs (Circa. 1984-1999)}

The largest number of Chinese BITs belong to the first generation (see Fig. 1).

The first eight pioneering BITs China entered into from 1982 to 1985 do not include ISDS provisions at all (see Appendix Table 2). China's initial reluctance to consent to investor-state arbitration (ISA) is partially due to the fact that China had not yet become a signatory party to the International Center for Settlement of Investment Disputes (ICSID) Convention until February 1993. ${ }^{5}$ However, this does not mean that the pre-1993 BITs China has concluded are fully insulated from ISA. The first Chinese BIT that envisages ISDS clauses is the China-Belgian-Luxembourg Economic Union (BLEU) BIT concluded in $1984 .^{6}$ Since then China entered into first generation BITs with ISDS provisions with the Netherlands in 1985 up until with Bahrain in 1999 (see Appendix Table 2).

First of all, the overwhelming majority of first generation Chinese BITs include the requirement of an amicable settlement of disputes through negotiation or consultation for a maximum period of six months as a prerequisite for investors to resort

\footnotetext{
${ }^{5}$ China signed the ICSID Convention on 9 February 1990, ratified on 1 July 1992 and deposited the instrument of ratification on 7 January 1993. The ICSID Convention became effective for China on 6 February 1993. ICSID, Membership, China, available at: https://icsid.worldbank.org/en/Pages/about/ MembershipStateDetails.aspx?state=ST30 (accessed 23 September 2020).

${ }^{6}$ Art. 10 of the China-Belgian-Luxembourg Economic Union (BLEU) BIT (1984) (Terminated and replaced by a renegotiated BIT in 2005).
} 


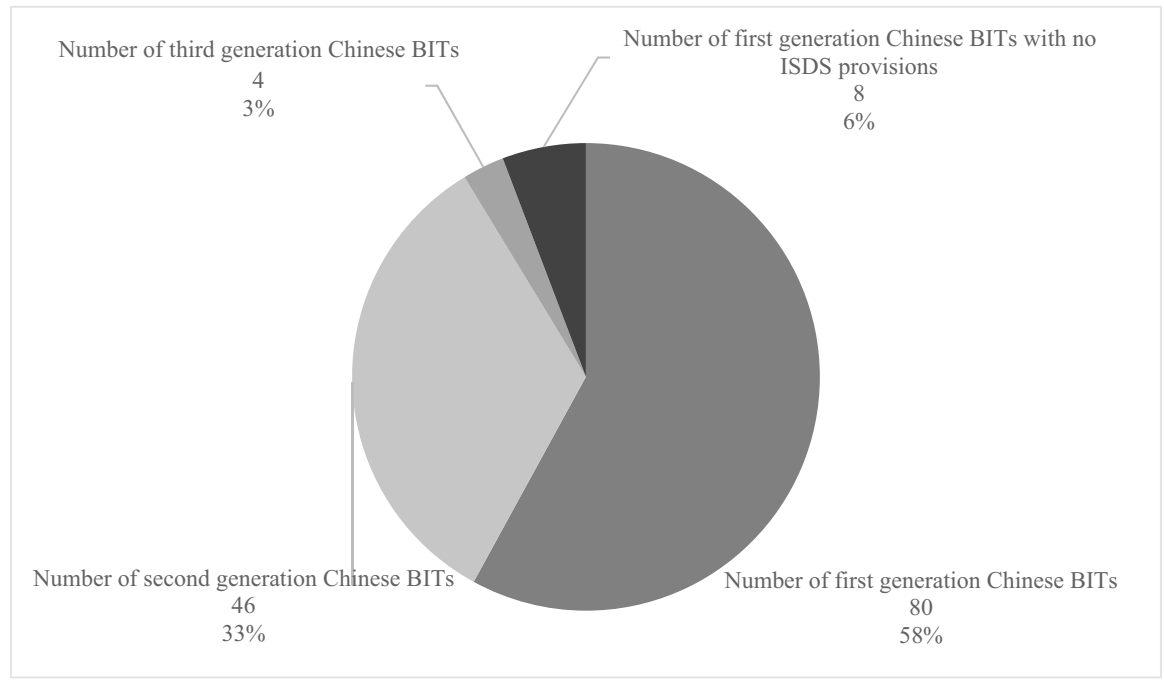

Fig. 1 Numbers of three generations of Chinese BITs. Source obtained from UNCTAD, Investment Policy Hub, IIA Navigator, China, available at: http://investmentpolicyhub.unctad.org/IIA/CountryBit s/42\#iiaInnerMenu (accessed 23 September 2020), and the Ministry of Commerce of China (MOFCOM), Department of Treaty and Law, Bilateral Investment Treaty, available at: http://tfs.mofcom.gov. cn/article/Nocategory/201111/20111107819474.shtml (accessed 23 September 2020). For a detailed mapping of ISDS in three generations of Chinese BITs, see Appendix Tables 2, 3 and 4 at the end of the article

to international arbitration. ${ }^{7}$ This is also known as the cooling-off period, during which the disputing parties may resort to amicable means in an attempt to resolve the dispute prior to resorting to ISA, including negotiation, conciliation or mediation (but excluding local administrative or judicial remedies). ${ }^{8} \mathrm{~A}$ few exceptions to this requirement can be found in 13 first generation Chinese BITs where no such a clause is provided, whereas in another five BITs either a longer or a shorter cooling-off period than the customary six-month one is stipulated (see Appendix Table 2).

Secondly, the ISDS provisions in first generation Chinese BITs include only the arbitrability of disputes concerning the amount of compensation for expropriation, although the formulation of these ISDS provisions is by no means consistent. ${ }^{9}$ In addition to a straightforward stipulation such as 'disputes concerning the amount of compensation referred to in Article 4 (expropriation), ${ }^{10}$ some BITs also admit

\footnotetext{
7 For example, Arts. 9.1 and 9.2 of the China-Netherlands BIT (1985) (Terminated) stipulated that: 'disputes between one Contracting Party and an investor of the other Contracting Party concerning an investment [...] shall, if possible, be settled amicably. If such disputes cannot be settled [...] within a period of six months from the date either party requested amicable settlement [...] the investor concerned may choose other means of resolution.'

8 Brauch (2017), p. 2.

9 Shan (2005), p. 200.

${ }^{10}$ E.g. Art. 10.2 of the China-Greece BIT (1992).
} 
disputes concerning measures by the host state of an expropriating effect, such as 'dispute involving the amount of compensation resulting from expropriation, nationalization, or other measures having an effect equivalent to nationalization or expropriation'. ${ }^{11}$

This limited scope of ISDS did not radically change after China's accession to the ICSID in 1993, as China retained its limited consent to ISA upon its ratification of the ICSID Convention by only adhering to the jurisdiction of the ICSID over compensation resulting from expropriation or nationalization. ${ }^{12}$ In 88 first generation Chinese BITs, only 18 of them provide the ICSID as an optional venue for arbitration, whilst the remaining 70 provide either arbitration ad hoc or no specified arbitration venue at all (see Appendix Table 2). The narrowly constructed scope of arbitration clauses results in compromised effectiveness and unsatisfactory protection in terms of the ISDS mechanism. ${ }^{13}$ Nevertheless, it is deemed to be a rational outcome in the specific economic and political context. Being a capital-importing country at the time, China had little incentive to protect its overseas investment; instead, the limitation of investors' access to ISDS was aimed at retaining the adjudicative prerogatives within domestic courts in settling disputes with foreign investors. ${ }^{14}$

However, only an extremely rare proportion of first generation Chinese BITs require the exhaustion of local remedies as a precondition before recourse to international arbitration. ${ }^{15}$ The China-Poland BIT (1988) stipulates that if an investor challenges the amount of compensation for the expropriated investment assets, he may file complaint with the competent authority of the Contracting Party taking the expropriatory measures. If it is not solved within one year after the complaint is filed, the competent court of the Contracting Party taking the expropriatory measures or an ad hoc international arbitral tribunal shall, upon the request of the investor, review the amount of compensation.' 16 The same stipulation is included in the China-Malaysia BIT (1988) and the China-Pakistan BIT (1989). ${ }^{17}$ This means that under these three BITs, investment disputes regarding the amount of compensation for expropriation must first be referred

\footnotetext{
11 E.g. Art. 13 of the China-Singapore BIT (1985).

12 China notified the ICSID on 7 January 1993 on its reservation to the ICSID Convention, stating that 'pursuant to Art. 25(4) of the Convention, the Chinese Government would only consider submitting to the jurisdiction of the ICSID disputes over compensation resulting from expropriation and nationalization.' ICSID, China, 'Notifications Concerning a Class or Classes of Disputes Which the Contracting State Would or Would Not Consider Submitting to the Jurisdiction of the Centre (Art. 25(4))' (7 January 1993), available at: https://icsid.worldbank.org/en/Pages/about/MembershipStateDetails.aspx?state =ST30 (accessed 23 September 2020).

13 Schill (2007), p. 91.

14 Chi and Wang (2015), pp. 873-874.

15 The exhaustion of local remedies is a requirement in international investment agreements, which means whenever an investment dispute arises, a foreign investor must first pursue and essentially exhaust the local remedies in the host state, whether administrative, judicial or both, for a specific period, before that investor may initiate arbitration proceedings against the host state. See Brauch (2017), p. 2; Amerasinghe (2004), pp. 267-276.

16 Art. 10.1 of the China-Poland BIT (1988).

17 Art. 7(1) of the China-Malaysia BIT (1988); Art. 10 of the China-Pakistan BIT (1989).
} 
to a competent administrative authority as a prerequisite for subsequent judicial recourse in the host state or international arbitration. In another ten first generation Chinese BITs local remedies are provided only as a choice for investors at their own discretion instead of a mandatory prerequisite prior to international arbitration (see Appendix Table 2). In the remainder of first generation Chinese BITs, there is no mention of local remedies at all.

With regard to the fork-in-the-road provision, 41 first generation Chinese BITs include the fork-in-the-road provision, where the choice of an investor to submit the dispute to either a domestic court or to international arbitration is deemed final and exclusive with regard to either one or the other (see Appendix Table 2).

As to the applicable law, 46 first generation Chinese BITs refer to the following sources: provisions of the BIT itself, the relevant domestic laws of both signatory parties, other agreements that both signatory states have concluded, and the generally recognized principles of international law (see Appendix Table 2). Obviously, both the fork-in-the-road provision and the applicable law provision have been negotiated on a case-by-case basis without a noticeable pattern being followed.

So far there are eight known investment arbitration cases pertaining to first generation Chinese BITs: four of which involve Chinese (including one Hong Kong and one Macao) investors as Claimants; ${ }^{18}$ and four concern China as the Respondent. ${ }^{19}$

\footnotetext{
18 Tza Yap Shum v. The Republic of Peru, ICSID Case No. ARB/07/6; China Heilongjiang International Economic \& Technical Cooperative Corp. et al. v. Mongolia, PCA Case No. 2010-20 (hereinafter China Heilongjiang v. Mongolia); Beijing Urban Construction Group Co. Ltd. v. Republic of Yemen, ICSID Case No. ARB/14/30; Sanum Investments Limited v. Lao People's Democratic Republic, UNCITRAL, PCA Case No. 2013-13 (hereinafter Sanum v. Laos).

In May 2019, two Chinese investors, Wuxi T. Hertz Technologies Co. Ltd. and Jetion Solar Co. Ltd., submitted a notice of arbitration to Greece to invoke arbitration under the China-Greece BIT (1992) concerning a photovoltaic project in Northern Greece, based on an alleged delayed licence needed for the commencement of the project. In December 2019, it was reported that the Chinese investors had withdrawn the notice of arbitration on the understanding that Greece would soon enact new legislation which would lead to the licensing of the project. IAReporter, 'Chinese Solar Investors Withdraw Investment Treaty Arbitration Against Greece' (3 December 2019), available at: https://www.iareporter.com/articles/ chinese-solar-investors-withdraw-investment-treaty-arbitration-against-greece/ (accessed 23 September 2020).

19 Ekran Berhad v. China, ICSID Case No. ARB/11/15. The Tribunal found that it had no jurisdiction as
} the claim was time-barred.

Macro Trading Co. Ltd. v. China, ICSID Case No. ARB/20/22. In June 2020, Macro Trading Co. Ltd., a Japanese investor in the construction sector, filed for arbitration against China based on the China-Japan BIT (1988), which contains first generation ISDS provisions. The case concerns disputes with regard to a real estate project in China, and is now in the process of appointing the remaining third arbitrator. Presumably, the contention of the case will be focused on either to adopt the narrow or broad interpretation of the 'amount of compensation for expropriation' in first generation Chinese BITs.

Jason Yu Song v. China, PCA Case 2019-39. In 2019, the PCA administered an investment arbitration filed by Jason Yu Song, a UK national, against China, based on the China-UK BIT (1986), which contains first generation ISDS provisions. Very little information regarding the case has been disclosed so far.

Goh Chin Soon v. China, ICSID Case No. ARB/20/34. Goh Chin Soon, a Singaporean businessman, initiated arbitration under the ICSID against China in September 2020, based on the China-Singapore BIT (1985) containing first generation ISDS provisions. It was reported that Goh had invested in several 
The most debated controversy with respect to these cases relates to the interpretation of 'disputes involving the amount of compensation for expropriation'. As a result, two schools of interpretation have been formed in investment adjudication. A broad view includes both the liability of expropriation (whether an expropriation act has taken place) and the quantification of compensation (the monetary amount to be compensated) as admissible disputes to arbitration, and a narrow view only admits the quantification of compensation to arbitration.

In Tza Yap Shum v. Peru, the Tribunal applied the 'ordinary meaning' approach to examine the semantic scope of the term 'involving' in Article 8(3) of the China-Peru BIT (1994). ${ }^{20}$ The Tribunal supported the broad view that the amount of compensation for expropriation includes 'not only the mere determination of the amount but also any other issues normally inherent to an expropriation, including whether the property was actually expropriated in accordance with the BIT provisions and requirements, as well as the determination of the amount of compensation due, if any'. ${ }^{21}$ When examining the Tza Yap Shum v. Peru case, a clearly expressed view is that a broad interpretation of the phrase 'disputes involving the amount of compensation for expropriation' is appropriate. ${ }^{22}$ Based on the narrow view, the investors would be allowed to resort to arbitration on the quantification of compensation due only after a domestic court of the host state has first officially proclaimed the existence of the act of expropriation. Whereas according to Article 8(2) and 8(3) of the China-Peru BIT, namely the fork-in-the-road provision, once the investor submits the dispute to domestic adjudication, it loses its eligibility to resort to international arbitration. ${ }^{23}$ Therefore, a narrow interpretation of 'the amount of compensation for expropriation' would result in the non-applicability of such an arbitration clause ipso jure. ${ }^{24}$ The Tribunal's broad view in Tza Yap Shum v. Peru 'effectively activates the practical utility' of the arbitration clause in first generation BITs, 'even though the Award does not have a precedential effect' ${ }^{25}$

In contrast, one commentator argues that, as a Communist country, China believes that domestic courts instead of international arbitral tribunals should be the sole judge that retains the authority to determine the ownership of property within China. ${ }^{26}$ Hence, China's original intention in negotiating first generation BITs was

\footnotetext{
Footnote 19 (continued)

real estate development projects in Qingdao City in the 1990s, allegedly worth over 1.5 billion USD, all of which were unlawfully expropriated by the local government. Lisa Bohmer, 'Singaporean Real Estate Developer Launches Treaty-based Arbitration against China' (IAReporter, 17 September 2020), available at: https://www-iareporter-com.eur.idm.oclc.org/articles/singaporean-real-estate-developer-launches-treat y-based-arbitration-against-china/ (accessed 23 September 2020).

${ }^{20}$ Tza Yap Shum v. The Republic of Peru, ICSID Case No. ARB/07/6, Decision on Jurisdiction and Competence, 19 June 2009, para. 151.

21 Tza Yap Shum v. The Republic of Peru, ICSID Case No. ARB/07/6, Award, 7 July 2011, para. 188.

22 Shen (2011), p. 77.

23 Tza Yap Shum v. The Republic of Peru, ICSID Case No. ARB/07/6, Decision on Jurisdiction and Competence, 19 June 2009, para. 187.

24 Reinisch (2011), p. 173.

25 Shen (2011), p. 94.

26 Willems (2011), p. 3.
} 
to adopt a narrow interpretation thereof, and the issue of the amount of compensation to be paid was only admissible to arbitration after a Chinese court had recognized the fact that there had been an act of expropriation, either lawful or unlawful, in the first place. $^{27}$

In Sanum v. Laos, the Laotian government challenged the jurisdiction of the Tribunal by relying on, inter alia, the argument that Article 8(3) of the China-Laos BIT (1993) only permitted arbitration of 'a dispute involving the amount of compensation for expropriation' and not 'disputes involving expropriation'. ${ }^{28}$ The Tribunal looked at the 'ordinary meaning' of the term 'involving', noted that 'it is also consistent with how a similar provision was interpreted by the Tza Yap Shum Tribunal', made a broad interpretation, and decided that it had jurisdiction because 'involving' should be interpreted as an inclusive term (and equal to 'including') rather than an exclusive one. ${ }^{29}$ The Laotian government then filed to vacate the Award on Jurisdiction for the Tribunal's lack of jurisdiction before the High Court in Singapore (SGHC), the seat of arbitration, which then supported Laos and annulled the Award, based on the principal reasoning that the Macau-incorporated Sanum did not qualify as an investor under the China-Laos BIT. ${ }^{30}$ SGHC also interpreted Article 8(3) of the China-Laos BIT, and came to a narrow interpretation of the term 'amount of compensation for expropriation'. The Judge placed strong emphasis on the context of the treaty and its historical background of negotiation, and relied on an assumption that two Communist states at the time of negotiation were more likely to intend for a restrictive arbitration clause in the China-Laos BIT in order to prioritize national judicial power in resolving investment disputes. ${ }^{31}$ This line of interpretation by the SGHC has been criticized as problematic, unnecessary and superfluous, because the Judge placed strong emphasis on the context of the treaty and its negotiating background in coming to his decision, but was neglectful of the object and purpose of the treaty in promoting foreign investment and protecting foreign investors. ${ }^{32}$

Sanum later appealed to the Singapore Court of Appeal (SGCA), which reversed the High Court's judgment and sustained the Tribunal's jurisdiction, in support of an expansive interpretation of Article 8(3). ${ }^{33}$ The SGCA adopted the "context, object and purpose' technique, as well as the principle of effet utile, to interpret Article 8(3), and argued that the fork-in-the-road provision in the China-Laos BIT, if under the narrow interpretation of the 'amount of compensation for expropriation', would bar investors from bringing a dispute to arbitration. ${ }^{34}$ Because once an investor submits the dispute on expropriation and any issues relating to it to a domestic

\footnotetext{
27 Rooney (2007), p. 703.

28 Sanum v. Laos, Award on Jurisdiction, 13 December 2013, para. 145.

29 Ibid., para. 329.

${ }^{30}$ Lao Republic v. Sanum, High Court of Singapore, [2015] SGHC 15, Judgement, 20 January 2015, para. 111.

31 Ibid., paras. 123-126.

32 Hwang and Chang (2015), p. 522.

33 Sanum v. Lao Republic, Court of Appeal of Singapore, [2016] SGCA 57, Judgement, 29 September 2016, para. 150 .

34 Ibid., paras. 130-133.
} 
court of the host state, the fork-in-the-road provision will prevent the investor from submitting the same issues to arbitration. The SGCA's reliance on the fork-in-theroad provision to support a broad interpretation of the 'amount of compensation for expropriation' has been appraised as a 'meticulous examination' of the issue, and an 'influential and prominent' decision to 'avoid an illusory right to arbitration' to investors. ${ }^{35}$ The limitation of the SGCA's interpretative approach, however, is that it cannot be applicable to first generation Chinese BITs with no fork-in-the-road provisions in place. After the confirmation of the Tribunal's jurisdiction, the Tribunal decided in favour of Laos on the grounds of Sanum's bribery and bad faith in the operation of its investment and unfounded expropriation claims. ${ }^{36}$

In Beijing Urban Construction Group (BUCG) v. Yemen, the Tribunal concluded that the 'ordinary meaning' and scope of the text 'amount of compensation for expropriation' were not conclusive to reach either a narrow or broad reading thereof, and that the Tribunal had to move to the 'context, object and purpose' of the treaty. ${ }^{37}$ The Tribunal adopted a broad interpretation, by taking the view that 'the Contracting Parties intended to confer a real choice, not an illusory choice, on investors from their respective countries, and that the words "relating to the amount of compensation for expropriation" must, in context, be read to include disputes relating to whether or not an expropriation has occurred. ${ }^{38}$

In China Heilongjiang International Economic \& Technical Cooperative Corp. et al. v. Mongolia, the Tribunal viewed the plain meaning of 'involving' in Article 8(3) of the China-Mongolia BIT (1991) as a neutral one and could neither support a broad or a narrow interpretation. ${ }^{39}$ Moving to the 'context, object and purpose' of the treaty, the Tribunal rendered its Award, deciding on its lack of jurisdiction ratione materiae, as a narrow approach in interpreting Article 8(3) was adopted. ${ }^{40}$ The Tribunal took the view that 'a dispute involving the amount of compensation for expropriation' only 'describes a particular category of disputes', namely 'whether the compensation which is due [...] is equivalent to the value of the expropriated investments' after an expropriation act has formally been proclaimed by the host state, 'the occurrence of which is not contested' ${ }^{41}$ Therefore, the claimants' request to the Tribunal to first adjudicate whether Mongolia had expropriated the Claimants' investment fell outside of the Tribunal's jurisdiction. The decision in China Heilongjiang $v$. Mongolia marks a turning point in the adjudication of first generation Chinese BITs, as it is the first arbitration case where the Tribunal has adopted a narrow interpretation. Yet the issue of the narrow or broad interpretation of first generation Chinese BITs remains a subject of debate. ${ }^{42}$ In September 2017, the claimants

\footnotetext{
35 Hwang and Chang (2018), p. 180.

36 Sanum v. Laos, Award, 6 August 2019.

37 Beijing Urban Construction Group Co. Ltd. v. Republic of Yemen, ICSID Case No. ARB/14/30, Decision on Jurisdiction, 31 May 2017, para. 77.

38 Ibid., para. 87.

39 China Heilongjiang v. Mongolia, PCA Case No. 2010-20, Award, 30 June 2017, para. 446.

40 Ibid., para. 452

41 Ibid., paras. 445, 448.

42 Scharaw (2018), pp. 305-306.
} 
filed a Petition to the New York Southern District Court to annul the Award. ${ }^{43}$ The Court's order in 2019 confirmed the validity of the Award, stating that 'the Chinese companies, by initiating this arbitration, affirmatively arguing for the tribunal's jurisdiction, and vigorously participating in the seven-year-long arbitration proceedings, have waived their opportunity to object now to the arbitrators' ability to decide the arbitrability of the case. The Court therefore finds that the parties clearly and unmistakably agreed to place the question of arbitrability before the tribunal. ${ }^{44}$ The Court thus refrained from expressing any opinions on the accuracy of the Tribunal's analysis of the dispute.

The above four cases demonstrate how the identical wording 'disputes involving the amount of compensation for expropriation' in first generation Chinese BITs creates interpretative ambiguities and inconsistency in jurisprudence. In Tza Yap Shum v. Peru, Sanum v. Laos, and BUCG v. Yemen, the Tribunals supported a broad interpretation, whereas in China Heilongjiang v. Mongolia, the Tribunal decided otherwise. All four Tribunals claimed to adhere to Article 31 of the Vienna Convention on the Law of Treaties (VCLT) in terms of their interpretative techniques, namely, to interpret treaty provisions 'in good faith in accordance with the ordinary meaning to be given to the terms of the treaty in their context and in the light of its object and purpose', but emphasized different aspects and came to divergent conclusions. In Tza Yap Shum v. Peru and Sanum v. Laos, both Tribunals relied on the ordinary meaning of the term 'involving' to reach a broad view, whilst in BUCG v. Yemen and China Heilongjiang v. Mongolia, both Tribunals moved to the 'context, object and purpose' of the treaty, but the former adopted a broad view and the latter a narrow view. The inconsistency of adjudicating techniques and outcomes delivered by arbitral tribunals is further exacerbated by domestic courts. In Sanum v. Laos, the SGHC endorsed a narrow view, which was later overturned by the SGCA in support of a broad view, and confirmed the jurisdiction of the Tribunal. Whereas the New York Southern District Court confirmed the Tribunal's lack of jurisdiction on the ground of arbitrability.

Because of the lack of a prevailing or authoritative interpretation in adjudicating practice, and the fact that an interpretation given by any tribunals or national courts does not have a binding precedential effect for pending or future cases, first generation Chinese BITs cannot 'guarantee a formalistic, formulaic or recitative interpretation' ${ }^{45}$ The inconsistency problem emanated in the adjudication manifests the inherent drawback of the current ad hoc investor-state arbitration mechanism. This creates uncertainty and a great potential for more inconsistent outcomes in future arbitration cases when first generation Chinese BITs are involved, inter alia in the three new pending cases where China is the Respondent. ${ }^{46}$

\footnotetext{
43 Beijing Shougang Mining Investment Company, Ltd. et al. v. Mongolia, No. 1:2017cv07436-Document 5 (S.D.N.Y. 2017).

44 Beijing Shougang Mining Investment Company, Ltd. et al. v. Mongolia, No. 1:2017cv07436-Document 21 (S.D.N.Y. 2019), p. 1.

45 Shen (2011), p. 94.

46 These three cases refer to Macro Trading Co. Ltd. v. China, ICSID Case No. ARB/20/22; Jason Yu Song v. China, PCA Case 2019-39; and Goh Chin Soon v. China, ICSID Case No. ARB/20/34. See above n. 19 .
} 


\section{ISDS in Second Generation Chinese BITs (Circa. 1997-2011)}

The second generation Chinese BITs incorporate ISDS clauses with a broad scope, representing an amicable shift towards the elimination of the admissibility hurdle against investors in the past. ${ }^{47}$ It starts with the China-South Africa BIT in December 1997, which stipulates that any dispute between an investor of one contracting Party and the other Contracting Party in connection with an investment is eligible to be resolved by international arbitration. ${ }^{48}$ The next second generation BIT China signed is the China-Barbados BIT (1998), which stipulates that 'any dispute concerning an investment between an investor of one Contracting Party and the other Contracting Party' is admissible to investment arbitration. ${ }^{49}$ Article 9 of the China-Barbados BIT has since then become exemplary for later second generation Chinese BITs.

Featured with the abandonment of restrictive arbitration clauses in previous BITs and the adoption of an extended and liberalized consent to international arbitration, as many as 46 Chinese BITs belong to the second generation (see Appendix Table 3). 24 of them have provided that any investment dispute can be brought to international arbitration, which is referred to as the 'investment requirement' (see Appendix Table 3). The scope and meaning of 'investment' are subsequently referred to in the investment definition clause in the same BIT. ${ }^{50}$ Furthermore, six second generation Chinese BITs stipulate that any legal dispute between an investor of one contracting party and the other contracting party is admissible to investment arbitration, starting from the China-Congo BIT (2000), which is referred to as the 'legal requirement' ${ }^{51}$ In addition, seven second generation Chinese BITs combine the 'legal requirement' and the 'investment requirement', meaning that any legal

\footnotetext{
${ }^{47}$ Chi and Wang (2015), p. 884.

48 Arts. 9.1 and 9.2 of the China-South Africa BIT (1997).

49 Art. 9 of the China-Barbados BIT (1998).

${ }^{50}$ Such an 'investment requirement' in second generation Chinese BITs might also invoke controversy with regard to the approaches in applying the term. In ISDS jurisprudence, several tribunals have grappled with the phrase 'any dispute in connection with an investment', and reached divergent interpretations thereof. E.g., in Salini et al. v. Morocco, the Tribunal made an expansive interpretation of the phrase, allowing for its jurisdiction not only over disputes arising out of a treaty violation, but also contractual claims made by the investor. To the contrary, in $S G S$ v. Pakistan, the Tribunal took a restrictive approach by interpreting the formulation of 'disputes with respect to investments' in a strictly descriptive way, thus dismissing all contractual disputes claimed by the investor. See Salini Costruttori S.p.A. and Italstrade S.p.A. v. Kingdom of Morocco, ICSID Case No. ARB/00/4, Decision on Jurisdiction, 23 July 2001, para. 61; SGS Société Générale de Surveillance S.A. v. Islamic Republic of Pakistan, ICSID Case No. ARB/01/13, Decision on Objections to Jurisdiction, 6 August 2003, para. 161.

${ }^{51}$ Due to the lack of any further definitions in second generation Chinese BITs, the term 'legal dispute' might be subject to interpretation by other sources of international law. In a general understanding, the legal requirement may be explained to exclude certain disputes such as moral, political, or purely contractual claims made by investors. See Shen (2010), p. 403.

In Saipem S.p.A. v. Bangladesh, the Tribunal addressed the 'legal' nature of an admissible dispute, and developed a relatively clear standard, asserting that the legal dispute should concern 'the existence or scope of legal rights', or 'the nature and extent of the relief to be granted as a result of the alleged violation of those legal rights'. Saipem S.p.A. v. People's Republic of Bangladesh, ICSID Case No. ARB/05/7, Decision on Jurisdiction, 21 March 2007, para. 95.
} 
dispute in connection with an investment is admissible to international arbitration (see Appendix Table 3). ${ }^{52}$ Despite the miscellaneous wording that they adopt, it is certain that all three types of formulation of the consent clause in second generation Chinese BITs are broad in nature.

The stipulation of the exhaustion of local remedies in second generation Chinese BITs is introduced by the China-South Africa BIT (1997). Article 9.2 of this BIT stipulates that if the dispute cannot be settled through negotiations within six months, either Party to the dispute shall be entitled to submit the dispute to an international arbitral tribunal provided that the Contracting Party involved in the dispute may [emphasis added] require the investor to initiate administrative review procedures in accordance with its laws and regulations. ${ }^{53}$ The same stipulation is observed in another 17 second generation Chinese BITs (see Appendix Table 3). This means that in these 18 second generation Chinese BITs, the requirement of the exhaustion of local remedies before recourse to arbitration is optional at the discretion of the host state. The wording 'may' indicates that the exhaustion of an administrative review procedure is not a treaty requirement established by the BIT at issue, but only a possible request by the host state. Yet, in a further four second generation Chinese BITs, starting with the China-Côte d'Ivoire BIT (2002), the requirement of the exhaustion of an administrative review procedure prior to international arbitration is obligatory (see Appendix Table 3). Article 9.3. of the China-Côte d'Ivoire BIT (2002) stipulates that 'if dispute cannot be settled amicably through negotiations, any legal dispute between an investor [...] and the other Contracting Party in connection with an investment [...] shall [emphasis added] exhaust the domestic administrative review procedure specified by the laws and regulations of that Contracting Party, before the submission of the dispute aforementioned to an arbitration procedure. ${ }^{54}$ For the rest of second generation Chinese BITs, no such provisions are provided.

In addition, 29 second generation Chinese BITs provide a conventional fork-inthe-road clause, whereas starting with the China-Latvia BIT (2004), four of them provide fork-in-the-road provisions that also allow a reversal to international arbitration under certain circumstances. ${ }^{55}$ A fork-in-the-road provision means once an investor has submitted the dispute either to a competent domestic court or to ISA, the choice of one of the two procedures shall be final. Whereas conditional reversal refers to the situation when an investor who has submitted the dispute to a national court may nevertheless have recourse to investment arbitration, if the investor has withdrawn the case from the national court before any judgment has been delivered on the subject matter. The emergence of the fork-in-the-road provision with conditional reversal in second generation Chinese BITs marks a critical transition from the first generation Chinese BITs, as it could result in a greater freedom of choice

\footnotetext{
52 E.g. Art. 9.1 of the China-Myanmar BIT (2001) stipulates that 'any legal dispute between an investor of one Contracting Party and the other Contracting Party in connection with an investment in the territory of the other Contracting Party [...]' shall be admissible to international arbitration.

53 China-South Africa BIT (1997).

54 Art. 9.3 of the China-Côte d'Ivoire BIT (2002).

55 Art. 9.2 of the China-Latvia BIT (2004); Art. 9.3 of the China-Finland BIT (2004); Art. 9.4 of the China-Slovakia Additional Protocol (2005); Art. 11.4 of the China-Switzerland BIT (2009).
} 
between national courts and international arbitration by foreign investors, and promote, in theory, the rule of law in the domestic judicial system 'by exposing national courts to competition with and scrutiny by international arbitration tribunals' ${ }^{56}$

With regard to the applicable law, 29 out of 46 second generation Chinese BITs contain the governing law by which the arbitral tribunal shall abide during adjudication. In comparison with the first generation Chinese BITs where the governing law includes the domestic laws of both signatory parties, the governing law in second generation Chinese BITs refers only to the domestic law of the host state, including its rules on the conflict of laws, in addition to the provisions of the BIT at issue and the applicable principles of international law. ${ }^{57}$

In comparison with the narrowly constructed ISDS provisions in first generation Chinese BITs, second generation Chinese BITs have resulted in a much broader coverage of access to international arbitration. Such a drastic policy shift is attributed to a synergy of economic, geo-political and historical factors. One of the most significant reasons for this shift is that China has attempted to protect its outbound investment 'without much probability of being involved as a respondent in any investorstate dispute', as China has gradually started to become a capital-exporting country investing in developing countries. ${ }^{58}$ As a matter of fact, out of the 46 second generation Chinese BITs, 37 signatory states are developing countries located in Africa, South East Asia and Latin America, which are commonly considered as capitalimporting countries (see Appendix Table 3). The liberal ISDS provisions aim to provide more potent protection to Chinese outbound investment against risks abroad due to unforeseeable host governments' intervention in business activities. ${ }^{59}$

There are three arbitration cases involving second generation Chinese BITs: Ping An Insurance Company v. Belgium lodged in 2012, ${ }^{60}$ Ansung Housing v. China lodged in 2014, ${ }^{61}$ and Hela Schwarz GmbH v. China lodged in $2017 .^{62}$

\footnotetext{
56 Hadley (2013), p. 305.

57 E.g., Art. 9.6 of the China-Barbados BIT (1998) stipulates that 'the arbitral tribunal shall decide the issues in dispute in accordance with the provisions of this Agreement, the law of the Contracting Party accepting the investment and applicable rules of international law'.

58 Cai (2006), p. 646.

59 Schill (2007), p. 76.

60 Ping An Life Insurance Company, Limited and Ping An Insurance (Group) Company, Limited v. The Government of Belgium, ICSID Case No. ARB/12/29 (hereinafter Ping An v. Belgium).

61 Ansung Housing Co. Ltd. v. People's Republic of China, ICSID Case No. ARB/14/25. The claim arose out of China's provincial government's alleged actions (a refusal to sell additional land to Ansung to complete its project already under construction) in respect of Ansung's investment in building a golf club in China. Ansung filed a request for ICSID arbitration in 2014 under the China-South Korea BIT (2007). The Tribunal ruled in the host state's favour, on the ground that the claim was rendered time-barred, according to the three-year limitation period stipulated in the BIT.

62 Hela Schwarz GmbH v. People's Republic of China, ICSID Case No. ARB/17/19. In May 2017 Hela Schwarz GmbH, a German spice and food additive manufacturer, brought a claim to the ICSID against China under the China-Germany BIT (2003). The Claimant objected that an illegitimate expropriation was carried out against it by the local government and the compensation amount was largely undervalued, invoking a breach of Art. 9 of the China-Germany BIT on Expropriation and Compensation. The Tribunal was constituted in January 2018, and the case is still pending.
} 
When a newly negotiated second generation Chinese BIT replaces its preceding first generation, a transition clause that specifies the temporal jurisdiction of two successive BITs is usually in place. The semantic scope of the transition clause, as demonstrated in the Ping An v. Belgium case, remains a central issue. This case concerns two BITs, namely the China-BLEU BIT (1984), which came into force in 1986, featuring a first generation ISDS clause, and the China-BLEU BIT (2005), which came into force in 2009, replacing the 1984 BIT and featuring a second generation ISDS clause. ${ }^{63}$ The Claimants filed a claim with the ICSID against Belgium in 2012, according to the arbitration clause of the 2005 BIT, ${ }^{64}$ but all substantive claims were made based on the obligations under the 1984 BIT. ${ }^{65}$ The Tribunal first observed that it was 'unequivocal' that the dispute arose before 2009, when the 2005 BIT came into force. ${ }^{66}$ The Tribunal then interpreted Article 8(1) of the 2005 BIT according to its 'plain meaning, ${ }^{67}$ and found that it was only applicable to disputes which only 'arise' after 2009, the time of the entry into force of the 2005 BIT, because the wording 'arises' cannot be interpreted as having the same meaning as 'arises or has arisen'. 68

The Claimant also relied on paragraph 2 of Article 10 of the 2005 BIT, namely the Transition Clause, to assert the Tribunal's jurisdiction over the dispute. Paragraph 2 stipulates that:

The present Agreement shall apply to all investments [emphasis added] made by investors of either Contracting Party in the territory of the other Contracting Party, whether made before or after the entry into force of this Agreement, but [emphasis added] shall not apply to any dispute [emphasis added] or any claim concerning an investment which was already under judicial or arbitral process before its entry into force. Such disputes and claims shall continue to be settled according to the provisions of the Agreement of 1984 mentioned in paragraph 1 of this Article.

The transition clause makes clear that the 2005 BIT does not cover disputes which arose and were already under judicial or arbitral process before 2009 , the time of the entry into force of the 2005 BIT. The point of contention was whether the

\footnotetext{
63 Agreement between the Government of the People's Republic of China and the Belgian-Luxembourg Economic Union on the Reciprocal Promotion and Protection of Investments (Terminated) (signed on 4 June 1984, effective on 5 October 1986). Agreement between the Government of the People's Republic of China and the Belgium-Luxembourg Economic Union on the Reciprocal Promotion and Protection of Investments (signed on 6 June 2005, effective on 1 December 2009).

64 Ping An v. Belgium, Award, 30 April 2015, para. 7.

65 Ibid., para. 85.

66 Ibid., para. 205.

67 Art. 8(1) of the China-BLEU BIT (2005) is headed 'settlement of investment disputes' and provides that: 'When a legal dispute arises [emphasis added] between an investor of one Contracting Party and the other Contracting Party, either party to the dispute shall notify the other party to the dispute in writing. As far as possible, the parties to the dispute shall endeavor to settle the dispute through consultations, if necessary by seeking expert advice from a third party, or by conciliation between the Contracting Parties through diplomatic channels.'

68 Ping Anv. Belgium, Award, 30 April 2015, para. 224.
} 
transition clause of the 2005 BIT covers disputes which arose, but were not under judicial or arbitral process, before the entry into force of the $2005 \mathrm{BIT}$, such as the dispute in Ping Anv. Belgium. The Tribunal took the view that the 2005 BIT does not expressly deal with such a dispute in contention, because paragraph 2 of Article 10 of the 2005 BIT only expressly covers investments made before or after the entry into force of the 2005 BIT, but not disputes arising out of those investments. To infer that 'investments' also implicitly include 'disputes arising out of such investments' would be a 'creative interpretation' and a gap which the Tribunal refused to fill. ${ }^{69}$ Consequently, the Tribunal decided on the lack of jurisdiction.

The Tribunal's interpretation received mixed reviews. A critical opinion on the Ping An v. Belgium Award is that the use of the adversative conjunction but in paragraph 2 of Article 10 of the 2005 BIT indicates that investments should also cover disputes concerning these investments. ${ }^{70}$ However, the Tribunal read 'investments' and 'dispute' in isolation, instead of as 'integral parts of one single sentence'. ${ }^{71}$ The Tribunal's approach in interpreting the 2005 BIT is problematic because it is doubtful whether the Tribunal actually complied with its avowed approach, where the Tribunal claimed to interpret Article 10 of the 2005 BIT 'in good faith' as required by Article 31 of the VCLT, and to 'not consider that a narrow and purely linguistic exercise is appropriate'. ${ }^{72}$ In contrast, a supportive opinion concerning the Tribunal's approach argues that the Tribunal's jurisdiction should only be based on 'the regular means of treaty interpretation', but not 'be presumed absent a clear text to that effect'. ${ }^{73}$ The Tribunal therefore 'provided a solid reasoning' and 'justified its choices'. ${ }^{74}$ It appears that either opinion accords with the principles of treaty interpretation in Article 31 VCLT, and cannot triumph over the other. The unresolved debate over the transition clause in Ping An v. Belgium raises concerns about uncertainty and inconsistency in future investor-state disputes regarding the temporal jurisdiction of successive Chinese BITs.

\section{ISDS in Third Generation Chinese BITs (Circa. 2007-2013)}

Since 2007, the coherence of second generation Chinese BITs has become less distinct, accompanied by the sporadic occurrence of a new modality of ISDS provisions. China started to deviate from the traditional lean European model of BIT-making, as followed by older generation Chinese BITs, and gravitated towards the US model that is more comprehensive and elaborate. ${ }^{75}$ It is believed that this policy shift is part of a greater move in the international investment regime to reformulate international investment

\footnotetext{
69 Ibid., para. 225.

70 Ren (2016), p. 133.

71 Ibid., p. 133.

72 Ibid., pp. 132-133.

73 De Brabandere and Lemeire (2017), para. 21.

74 Ibid., para. 22.

75 Some scholars have referred to this shift as one 'from Europeanization toward Americanization'. See, Chi (2017). In some scholarly references, the word Americanization is also interchangeably used with 'NAFTA-ization' or 'Westernization'. See Berger (2013b); Ji (2011).
} 
agreement (IIA) approaches aiming to recalibrate the relationship between the level of protection for foreign investors and the policy space of host country governments. ${ }^{, 76}$

The modified BIT with Cuba in 2007 marks the pioneer of third generation Chinese BITs. However, China later concluded BITs with Columbia, Switzerland, Mali, Malta and Uzbekistan respectively from 2008 to 2011, all of which still belong to the second generation (see Appendix Table 3). It is the conclusion of the China-Canada BIT signed in 2012 that epitomizes third generation Chinese BITs. Until the China-Tanzania BIT signed in 2013, which is the latest BIT that China has concluded, four Chinese BITs belong to the third generation (see Appendix Table 4).

For a start, one of the most noticeable traits of third generation Chinese BITs is the expansion of provisions on dispute settlement. Instead of 'ISDS provisions' that account for several clauses at best, third generation Chinese BITs usually feature designated dispute settlement chapters that contain elaborated articles. For instance, the China-Mexico BIT (2008) includes a whole chapter with as many as 17 articles specifically addressing ISDS, and the China-Canada BIT (2012) establishes a part that includes 13 ISDS articles. ${ }^{77}$ Third generation Chinese BITs 'seem to indicate China is willing to negotiate detailed and highly prescriptive dispute resolution provisions'. ${ }^{78}$ In comparison, the dispute settlement section in the US Model BIT 2012 comprises 14 articles, constituting one third of the whole text. ${ }^{79}$ This demonstrates the paradigm shift China takes in negotiating BITs that becomes analogous to the elaborated US model.

Second, third generation Chinese BITs require the amicable settlement of disputes in a cooling-off period of six months (four months in the China-Canada BIT) before resorting to arbitration, starting from the date of the investor's submission of notification of intent to arbitration. ${ }^{80}$ An investor is obliged to first submit a notification of intent to arbitration to the host state regarding the fundamental issues as well as the factual and legal basis of the claim, in order to give the host state a 'heads up' before the host state responds in the arbitration proceedings, and to avoid frivolous arbitration or claims with no legal merit. Such a stipulation originates from the 2004 US model BIT, where a notice of intent to the host state is required at least 90 days before filing a claim to arbitration. ${ }^{81}$

Third, this generation of Chinese BITs admit an investment dispute to international arbitration where an investor or its investment has incurred loss or damage by

\footnotetext{
76 Berger (2015), p. 850 .

77 Chapter III of the China-Mexico BIT (2008); Part C of the China-Canada BIT (2012).

78 Gallagher (2016), p. 103.

79 USTR, Treaty between the Government of the United States of America and the Government of [Country] Concerning the Encouragement and Reciprocal Protection of Investment, Section B (2012), available at: https://ustr.gov/sites/default/files/BIT\%20text\%20for\%20ACIEP\%20Meeting.pdf (accessed 23 September 2020) (hereinafter US Model BIT 2012). USTR, Treaty between the Government of the United States of America and the Government of [Country] Concerning the Encouragement and Reciprocal Protection of Investment, Section B (2004), available at: https://www.state.gov/documents/organ ization/117601.pdf (accessed 23 September 2020) (hereinafter US Model BIT 2004).

${ }^{80}$ Art. 9.3.1 of the China-Cuba BIT (2007); Art. 12 of the China-Mexico BIT (2008); Art. 21 of the China-Canada BIT (2012).

81 Art. 24.2 of the US Model BIT 2004. See also Caplan and Sharpe (2013), p. 826.
} 
reason of or arising from breaches of obligations under the applicable BIT. ${ }^{82}$ Third generation Chinese BITs further stipulate that only breaches of specific obligations under the BIT concerned are admissible to arbitration; admissible disputes are positively listed and are therein 'article specific' ${ }^{83}$ For instance, the China-Canada BIT only admits investment disputes to arbitration concerning breaches of specific provisions of the BIT which cause a loss or damage to the investor in relation to its investment. ${ }^{84}$ This means that third generation Chinese BITs demand a combination of a breach of article-specific treaty obligations and the requirement of actual damage therefrom, which consequently establishes a higher threshold of admissibility to ISA. Once again, this approach can be traced back to the same stipulations in the 2004 US Model BIT. ${ }^{85}$

Fourth, third generation Chinese BITs appear to be more selective in terms of the scope of consent to arbitration, as certain exclusions to ISDS are explicitly prescribed, in addition to the aforementioned admissibility requirements. For instance, the China-Canada BIT includes a 'negative list', in which specific provisions in the treaty are explicitly excluded from investor-state arbitration. In addition to the general exceptions that do not apply to the treaty as a whole, ${ }^{86}$ the China-Canada BIT also explicitly excludes the application of ISDS to disputes concerning prudential measures in the financial sector, which may eventually be resolved by state-to-state arbitration. ${ }^{87}$ Disputes over taxation measures are also excluded from investor-state arbitration. ${ }^{88}$ Finally, a decision made by China or Canada under national laws and regulations regarding the approval of an investment, or a national security review, is excluded from investor-state arbitration. ${ }^{89}$ The 'negative list' approach is also a feature that first appeared in the US model BIT 2004. ${ }^{90}$

Fifth, the most-favoured-nation (MFN) treatment in third generation Chinese BITs is explicitly excluded from the dispute settlement mechanism. ${ }^{91}$ This means that foreign investors are not able to invoke the MFN clause in third generation Chinese BITs to import a more favourable, or otherwise a less burdensome procedural

\footnotetext{
82 Art. 13.1 of the China-Mexico BIT (2008); Art. 20.1 of the China-Canada BIT (2012); Art. 13.2 of the China-Tanzania BIT (2013).

83 Ibid.

84 Art. 20.1 of the China-Canada BIT (2012) stipulates that an investor may submit a claim to arbitration when the investor or its investment has incurred loss or damage by reason of, or arising out of breaches of obligations under Arts. 2 to 7(2), 9, 10 to 13, 14 (4) or 16 of the BIT.

85 Art. 24.1 of the US Model BIT 2004.

${ }^{86}$ Art. 33 of the China-Canada BIT (2012) stipulates that the general exceptions which do not apply to the whole BIT include measures in respect of cultural industries, environmental measures, measures for prudential reasons in the financial sector, measures of monetary policies, information of essential security interests or of confidentiality.

87 Art. 20 (2) of the China-Canada BIT (2012).

88 Art. 14 of the China-Canada BIT (2012).

89 Annex D.34 of the China-Canada BIT (2012).

90 Arts. 18-21 of the US Model BIT 2004.

91 E.g., para. 3, Art. 5 Most-Favored-Nation Treatment, of the China-Canada BIT (2012) stipulates that: "for greater certainty, the "treatment" referred to in paragraphs 1 and 2 of this Article does not encompass the dispute resolution mechanisms, such as those in Part C, in other international investment treaties and other trade agreements'.
} 
treatment from other BITs of which China is a party. The contention of whether the MFN clause should be applicable to procedural aspects, such as admissibility to international arbitration so that a tribunal can establish its jurisdiction based on the application of the MFN clause, has been widely addressed in international investment arbitration. As a matter of fact, inconsistent decisions have been made in multiple cases where different tribunals have either explicitly confirmed or rejected the applicability of the MFN clause for procedural benefits, be it an exemption from procedural preconditions or an extension of jurisdiction in order to successfully invoke an arbitration. For instance, in Emilio Agustin Maffezini v. Spain, ${ }^{92}$ and Gas Natural SDG, S.A. v. Argentina,${ }^{93}$ the Tribunals explicitly acknowledged the applicability of the MFN clause for procedural benefits; whereas in Salini Costruttori S.p.A. and Italstrade S.p.A. v. Jordan, ${ }^{94}$ and Plama Consortium Limited v. Bulgaria, ${ }^{95}$ the Tribunals explicitly rejected the application of the MFN clause to procedural matters. ${ }^{96}$ The interpretation of these Tribunals on whether the jurisdiction of a tribunal could be expanded by incorporating a more favourable treatment through the invocation of the MFN clause resulted in three schools: a definite 'yes' school, a definite 'no' school and an 'answer to the question cannot be formulated in general terms' school. ${ }^{97}$ With the lack of clear jurisprudence, it is worrisome that the interpretation of the MFN clause may well largely depend on a tribunal's own discretion on a case-by-case basis. In this context the third generation Chinese BITs provide a clear insulation from those ambiguities.

Sixth, the China-Mexico BIT and the China-Tanzania BIT provide fork-in-theroad provisions, whereas the China-Cuba BIT and the China-Canada BIT adopt the 'no U-Turn' clause that allows for a conditional retour: investors are allowed to have recourse to international arbitration even if the dispute has been submitted to domestic courts, as long as the investor waives the right to continue any proceedings in a court of the host state before a final judgment has been made. ${ }^{98}$

Seventh, an important shift in third generation Chinese BITs with regard to the applicable law to which a tribunal shall resort in resolving a dispute is the exclusion of the domestic law of the contracting states. For example, the China-Mexico BIT explicitly stipulates that 'a tribunal established [...] shall decide the issues in dispute in accordance with this Agreement and with the applicable rules and principles of international law, 99 The China-Canada BIT made an identical stipulation to that

\footnotetext{
92 Emilio Agustin Maffezini v. Kingdom of Spain, ICSID Case No. ARB/97/7, Decision on Objections to Jurisdiction, 25 January 2000.

93 Gas Natural SDG, S.A. v. The Argentine Republic, ICSID Case No. ARB/03/10, Decision on Preliminary Questions on Jurisdiction, 17 June 2005.

94 Salini Costruttori S.p.A. and Italstrade S.p.A. v. The Hashemite Kingdom of Jordan, ICSID Case No. $\mathrm{ARB} / 02 / 13$, Decision on Jurisdiction, 9 November 2004.

95 Plama Consortium Limited v. Republic of Bulgaria, ICSID Case No. ARB/03/24, Decision on Jurisdiction, 8 February 2005.

96 The cases in the above nn. 92-95 are cited from Douglas (2011), p. 98.

97 Ibid.

98 Art. 9.4.1.d of the China-Cuba Modification Agreement (2007); Annex C.21 of the China-Canada BIT (2012).

99 Art. 27 of the China-Mexico BIT (2008).
} 
in the China-Mexico BIT. ${ }^{100}$ In comparison with the governing law stipulated in the first and second generations Chinese BITs, the domestic laws of both signatory states may no longer be referred to by arbitral tribunals under the China-Mexico BIT and China-Canada BIT. The inclusion of domestic law as the governing law or the applicable law in ISDS is a mechanism which allows the host state to invoke its own municipal law to justify state measures that allegedly violate its treaty obligations. ${ }^{101}$ Hence, its exclusion would result in the elimination of the possibility of applying domestic laws and regulations as a defense in international investment arbitration. $^{102}$

Last but not the least, the China-Canada BIT is so far the most comprehensive and innovative investment agreement that China has concluded with a profound significance, in terms of the formulations it adopts as well as the implications thereof. ${ }^{103}$ It provides that: to ensure the impartiality and professionalism of the arbitrators, the tribunal shall comprise of three arbitrators, who are subject to specific qualification requirements. ${ }^{104}$ And to increase the efficiency of the tribunal, where two or more claims have been submitted separately to arbitration and the claims have a question of law or fact in common and arise out of the same events or circumstances, any disputing party may seek a consolidation order with the tribunal. ${ }^{105}$ To increase the transparency of the arbitration proceedings, any tribunal award, hearings and relevant documents are publicly available, subject to the redaction of confidential information. ${ }^{106}$ A tribunal may recommend an interim measure of protection to preserve the rights of a disputing party, or to ensure that the tribunal's jurisdiction is made fully effective, including a recommendation to preserve evidence in the possession or control of a disputing party. ${ }^{107}$ All of the above unique features in the China-Canada BIT are once again modelled upon respective clauses in the US Model BIT. ${ }^{108}$

Third generation Chinese BITs are prominent examples of how the Chinese government now seeks to negotiate ISDS chapters which strike a balance between the protection of investors and the preservation of the host state's right to regulate. A variety of exceptions and exclusions are stipulated to curb the arbitral tribunal's jurisdictional outreach and to ensure that it is not unlimited or overly expansive. At the same time, significant restrictions and higher procedural requirements are placed on investors to prevent frivolous or meritless claims. Therefore, third generation

\footnotetext{
100 Art. 19 of the China-Canada BIT (2012).

101 Lee (2013), p. 525.

102 Ibid.

103 Berger (2013a), p. 25.

104 Art. 21(1) of the China-Canada BIT (2012) stipulates that 'arbitrators shall have expertise or experience in public international law, international trade or international investment rules, or the resolution of disputes arising under international trade or international investment agreements; they should also be independent of, and not be affiliated with, or take instructions from, either disputing party'.

105 Art. 26 of the China-Canada BIT (2012).

106 Art. 28 of the China-Canada BIT (2012).

107 Art. 31(1) of the China-Canada BIT (2012).

108 Arts. 27-29 and 33 of the US Model BIT 2004.
} 
Chinese BITs recalibrate the liberal approach of ISDS in the second generation in an attempt to attain a more balanced ISDS scheme.

\section{The Making of the China-EU CAI and the China-US BIT: Towards a Fourth Generation}

China is in the process of negotiating BITs with the EU and the US. The ongoing negotiation of the China-EU CAI was officially launched in November $2013,{ }^{109}$ and is anticipated to reach a conclusion by the end of $2020 .{ }^{110}$ Once concluded, the CAI will replace the current 25 fragmented BITs that China has concluded with individual EU Member States. ${ }^{111}$ China and the US made their first attempt to negotiate a BIT from 1983 to 1987, which led to a void of any agreements due to the irreconcilable positions on many critical aspects. ${ }^{112}$ In 2008 , China and the US commenced a new negotiation for a BIT which seemed to have achieved near completion in 2016. ${ }^{113}$ However, since President Trump took office, the negotiation has come to a halt.

Both the China-EU CAI and the China-US BIT are expected to inaugurate a new generation of BITs because of their comprehensive scope and unprecedented contents. ${ }^{114}$ Despite the lack of a treaty, under pressure from the US, China has agreed to further open its market entry to foreign investment by introducing pre-establishment national treatment with a negative list system, which has been established in China's new Foreign Investment Law entered into force on 1 January $2020 .^{115}$

With regard to ISDS, the CAI and the China-US BIT may demonstrate some fundamental disparities. The EU is a determined proponent for the reform of ISDS by proposing a bilateral Investment Court System (ICS), to be eventually replaced by a Multilateral Investment Court (MIC), which have been integrated into the EUCanada Comprehensive Economic and Trade Agreement (CETA), the EU-Vietnam Investment Protection Agreement (IPA) and the EU-Singapore IPA. This makes the

\footnotetext{
109 Iuliu Winkler, 'Legislative Train Schedule, EU-China Comprehensive Agreement on Investment' (European Parliament, 4 September 2020), available at: http://www.europarl.europa.eu/legislative-train /theme-a-balanced-and-progressive-trade-policy-to-harness-globalisation/file-eu-china-investment-agree ment (accessed 23 September 2020).

110 This time goal was first announced at the $21^{\text {st }}$ EU-China Summit held in April 2019. European Council, 'Joint Statement of the $21^{\text {st }}$ EU-China Summit' (Brussels, 9 April 2019), available at: https://www. consilium.europa.eu/media/39020/euchina-joint-statement-9apri12019.pdf (accessed 6 November 2020).

111 China has concluded 25 BITs with the individual EU Member States except for Ireland. Belgium and Luxembourg have jointly negotiated a BIT with China.

112 Cai (2009), p. 486.

113 Shannon Tiezzi, 'Are China and the US Close to Sealing an Investment Treaty?' (The Diplomat, 24 March 2016), available at: https://thediplomat.com/2016/03/are-china-and-the-us-close-to-sealing-aninvestment-treaty/ (accessed on 23 September 2020).

114 On the new generation of global IIAs, see Titi (2015), pp. 654-657; Schill and Bray (2017).

115 Arts. 4 and 28 of China's Foreign Investment Law. Pre-establishment national treatment means that China grants no less favourable treatment to foreign investors and their investment at the market entry stage than to domestic investors and their investment. The negative list refers to a list of specific sectors and activities in which foreign investors are either prohibited or restricted from entering the Chinese market.
} 
EU a determined 'systemic reformer' of investor-state arbitration. ${ }^{116}$ By contrast, the US is traditionally an 'incrementalist' in ISDS reform, as it favours the retention of the current ad hoc investor-state arbitration while proposing modest reforms that address specific concerns with regard to the current system. ${ }^{117}$ China has a tradition of adopting a negotiation strategy for BITs that is in deference to the other contracting party. ${ }^{118}$ For that reason, there is a possibility that the China-EU CAI would incorporate the unprecedented ICS that is explicitly advocated by the EU. The China-US BIT, provided that a BIT is still a desired option at all, would most likely retain the conventional ad hoc investment arbitration with restrictive characteristics as adopted in the United States-Mexico-Canada Agreement (USMCA).

\section{Challenges and Tentative Solutions to ISDS in the context of the Belt and Road Initiative}

China's extensive BIT regime inevitably creates inconsistency in terms of the different levels of protection for foreign investors and the fragmentation of foreign investors' access to ISDS. This is the case in particular with countries participating in the BRI. The BRI is China's grand national campaign announced by President Xi Jinping in 2013 that promotes connectivity and cooperation in cross-border trade and investment, global infrastructure development, financing, and people-to-people exchange between China and more than 100 participating countries. This section reveals the high legal risks of Chinese investments in BRI countries due to the diversified levels of the rule of law in these BRI countries, and the lack of access to, or insufficient access to ISDS in Chinese BITs signed with BRI countries. Further, this section expounds on two tentative solutions that China has adopted to facilitate dispute resolution in the BRI, namely to modernize Chinese BITs on a case-by-case basis, and to promote Chinese domestic institutions to resolve transnational disputes, as well as their respective shortfalls and limitations.

\subsection{Risks and Uncertainties in Investment Dispute Settlement in the BRI}

By the end of January 2020, China has signed Memoranda of Cooperation with 138 countries concerning the BRI. ${ }^{119}$

Figure 2 demonstrates that out of 138 BRI countries, 41 of them (30\%) have not concluded BITs with China, and 60 of them (44\%) have first generation BITs with China. This suggests that altogether 101 BRI countries have either no investment agreements with China or have restricted access to ISDS that only admits disputes relating to the amount of compensation for expropriation, accounting for $74 \%$ of the total BRI countries. And the remaining 37 BRI countries have second or third

\footnotetext{
116 Roberts (2018), p. 416.

117 Ibid., p. 415.

118 Berger (2011).

119 A 'BRI country' is a loosely defined term. In this article, we define a BRI country as one which has officially signed a Memorandum of Cooperation with China to participate in the BRI. Belt and Road Portal, International Cooperation, Profiles, available at: https://www.yidaiyilu.gov.cn/xwzx/roll/77298.htm (accessed 23 September 2020).
} 


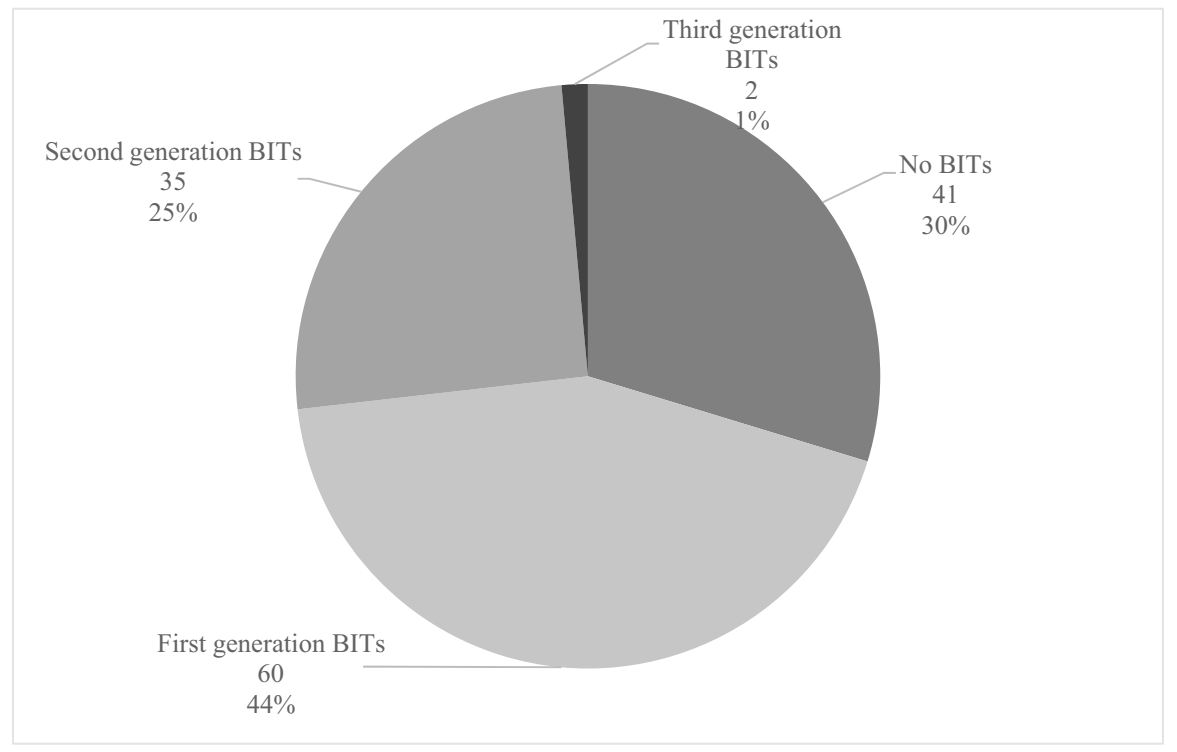

Fig. 2 Three generations of Chinese BITs with BRI countries. Statistics compiled by the authors

generation BITs with China. Of the 97 BITs China has signed with BRI countries, 9 of them have been renegotiated, as new BITs or Additional Protocols have replaced or modified previously concluded BITs. ${ }^{120}$

It appears doubtful whether it would be a sound strategy to invest in countries that are less economically developed, lack political and social stability and safety, and have a weak rule of law and potential neglect to property rights. ${ }^{121}$ To use 41 BRI countries that do not have BITs with China as a sample, the overwhelming majority of them are developing countries, some of which are the world's least-developed countries, with 17 in Africa, and the remainder in Oceania, Central and South America, South Asia and the Middle East (see Table 1). In terms of the level of the rule of law, these 41 BRI countries can be particularly problematic. According to the Rule of Law Index 2019, out of 20 of these 41 BRI countries where rankings are available in the Index, 13 of them rank in the lower half of the entire ranking system (after the median ranking No. 63). ${ }^{122}$ Notably, several countries that occupy the lowest rankings in the Rule of Law Index, inter alia, Venezuela (No. 126), Afghanistan (No.

\footnotetext{
120 They include the China-Uzbekistan BIT (2011) replacing the China-Uzbekistan BIT (1992), the China-Cuba Modification Agreement (2007) modifying the China-Cuba BIT (1995), the China-Bulgaria Additional Protocol (2007) modifying the China-Bulgaria BIT (1989), the China-Russia BIT (2006) replacing the China-Russia BIT (1990), the China-Slovakia Additional Protocol (2005) modifying the China-Czechoslovakia BIT (1991), the China-Portugal BIT (2005) replacing the China-Portugal BIT (1992), the China-BLUE BIT (2005) replacing the China-BLUE BIT (1984), the China-Nigeria BIT (2001) replacing the China-Nigeria BIT (1997), and the China-Romania Additional Protocol (2007) modifying the China-Romania BIT (1994).

121 Ferdinand (2016), pp. 952-953.

122 World Justice Project, Rule of Law Index 2019, available at: http://data.worldjusticeproject.org/\#table (accessed 23 September 2020).
} 
Table 1 BRI countries with no BITs with China and their rankings (out of a total of 126 countries) in the Rule of Law Index 2019

\begin{tabular}{|c|c|c|c|c|}
\hline Africa & $\begin{array}{l}\text { Asia and Middle } \\
\text { East }\end{array}$ & Europe & Americas & Oceania \\
\hline Senegal 52 & Timor-Leste - & Montenegro - & Venezuela 126 & Samoa - \\
\hline Somalia - & Vietnam 81 & Estonia 10 & Suriname 69 & Niue - \\
\hline South Sudan - & Nepal 59 & & Panama 64 & Fiji - \\
\hline Zambia 92 & Maldives - & & El Salvador 84 & $\begin{array}{l}\text { Federated States of } \\
\text { Micronesia - }\end{array}$ \\
\hline Mauritania 122 & Iraq - & & Dominican Republic 95 & Cook Islands - \\
\hline Angola 111 & Afghanistan 123 & & Antigua and Barbuda 33 & Tonga - \\
\hline Chad - & & & Dominica 45 & Solomon Islands - \\
\hline Burundi - & & & Grenada 43 & Kiribati - \\
\hline \multicolumn{5}{|l|}{ Cape Verde - } \\
\hline \multicolumn{5}{|l|}{ Gambia - } \\
\hline \multicolumn{5}{|l|}{ Togo 100} \\
\hline \multicolumn{5}{|l|}{ Rwanda 40} \\
\hline \multicolumn{5}{|l|}{ Libya - } \\
\hline \multicolumn{5}{|l|}{ Liberia 97} \\
\hline \multicolumn{5}{|l|}{ Lesotho - } \\
\hline \multicolumn{5}{|l|}{ Comoros - } \\
\hline Niger 104 & & & & \\
\hline
\end{tabular}

Statistics compiled by the authors. Source obtained from World Justice Project, Rule of Law Index 2019, available at: http://data.worldjusticeproject.org/\#table (accessed 23 September 2020). The 2019 Index covers 126 countries and jurisdictions, '-' means data from that country is not available

123), Mauritania (No. 122), and Angola (No. 111), are also BRI countries without BITs with China (see Table 1). This means that a weak rule of law is a prevalent feature in BRI countries with which China has not concluded BITs.

When an investment dispute arises between China and one of these 41 BRI countries that has not concluded any BIT with China, a Chinese investor would either resort to legal remedies in the domestic courts, commercial arbitration (in the event that state sovereign immunity does not apply), or both governments will have to intervene and resolve the dispute in diplomatic ways. Resorting to the national courts of the recipient BRI country could be unreliable due to its inadequate level of the rule of law, and resorting to a Chinese domestic court or international commercial arbitration leads to the enforcement of foreign judgments or foreign arbitral awards by the national courts of a BRI country, which could be equally problematic. Some disputes with BRI countries are resolved through political and diplomatic channels, but this leads to accusations that the Chinese government's strategy is intended to create wellorchestrated debt traps and to gain negotiating leverage in geopolitical duelling with its neighbouring countries. ${ }^{123}$ One of the most cited cases of China's alleged debt trap diplomacy with BRI countries is China's investment in Sri Lanka, with which

123 Zhao (2019), p. 10. 
China has no BIT, to build the Hambantota Port. Two Chinese state-owned enterprises (SOEs), China Harbor Engineering Company and Sinohydro Corporation, are the contractors to build the Port, at a price of 361 million USD, 85\% of which was loaned to the Sri Lankan government by China's state-owned Export-Import Bank at an annual interest rate of $6.3 \%$. When the Sri Lankan government failed to pay its debt in 2017, conditions were negotiated, including a 99-year lease of the Port to China Merchants Port Holdings Co. Ltd., and China Merchants Port Holdings' 70\% ownership of the parent company of the Hambantota Port, in exchange for writing off the entire debt. ${ }^{124}$ This case was epitomized as a notorious example of China's insidious strategy to expand its political and economic influence and to gain control over critical infrastructure in other BRI countries, and ultimately to debilitate the state sovereignty of the host BRI country. ${ }^{125}$ This case demonstrates how using a statestate mechanism to solve investment disputes can often lead to politicization.

Some 60 BRI countries (44\%) have a first generation BIT with China, meaning that only disputes concerning the amount of compensation for expropriation may resort to ISA. Due to the controversial and ambiguous nature of the term 'amount of compensation for expropriation' in first generation Chinese BITs as contested in Tza Yap Shum v. Peru, Sanum v. Laos, BUCG v. Yemen, and China Heilongjiang et al. v. Mongolia with inconsistent arbitral outcomes, Chinese investors are placed in a rather unpredictable scenario when invoking arbitration under a first generation Chinese BIT. For disputes regarding matters other than compensation, such as an alleged breach of fair and equitable treatment, investors are not able to resort to arbitration under a first generation Chinese BIT at all. The limited scope of the arbitration clause in first generation Chinese BITs results in insufficient protection being granted to Chinese investors in BRI countries.

\subsection{Upgrading the Chinese BIT Regime on a Case-by-Case Basis}

China has strong incentives to upgrade BITs with BRI countries. First, it is in China's fundamental interest as a home country to upgrade its BIT regime. Considering the fact that some Chinese investment in BRI countries is massive in scale, involves high risks, and that Chinese investors have either no access or very limited access to ISDS, it is in China's interest to formulate a coherent strategy to negotiate or upgrade BITs with BRI countries so as to provide a high level of investment protection and an effective and predictable ISDS mechanism in a unified term. Second, it is also in China's fundamental interest as a host country to modernize its BIT regime in general. The divergent ISDS provisions in Chinese BITs expose China to a position of facing potentially a large amount of claims as a result of the 'out-of-fashion' ISDS provisions. ${ }^{126}$ This is particularly the case in second generation Chinese BITs which cover 'any disputes in connection to an investment' or 'any legal disputes', as

\footnotetext{
124 Carrai (2019).

125 Ibid.

126 Zhang (2017), p. 99.
} 
these broadly stipulated terms grant virtually unlimited access to ISDS and would thus potentially entail a large number of claims against China in the future. ${ }^{127}$

China has so far adopted four models to upgrade its BITs: ${ }^{128}$

- A Coexistence Model (parties to a BIT join an FTA with investment provisions and both are in effect);

- A Replacement Model (a newly negotiated BIT replaces an old one);

- An Amendment Model (partially amending a BIT with a protocol);

- A Joint Interpretation Model (parties make diplomatic statements to interpret an existing BIT).

Using these four methods simultaneously, China has upgraded 32 BITs, accounting for $28 \%$ of all Chinese BITs concluded. The most frequently used model is the Coexistence Model (18 BITs), followed by the Replacement Model (12 BITs), the Amendment Model (4 BITs), and the Joint Interpretation Model (the only example being two diplomatic statements made by Laos and China in Sanum v. Laos). ${ }^{129}$

To upgrade Chinese BITs on a case-by-case basis creates some hardship. It is first and foremost an arduous and onerous task, concerning the significant amount of effort and time that are required to renegotiate more than 100 Chinese BITs that are in force on a case-by-case basis. In addition, the renegotiation of Chinese BITs does not guarantee consistency in their ISDS clauses, because the substance of each BIT is a result of consensus by both negotiating parties, and China's negotiating parties' diversified positions and approaches on ISDS would still lead to fragmented ISDS provisions in China's BIT regime as a whole. Furthermore, China's policy on ISDS reform, other than the identified three generations of ISDS provisions in Chinese BITs, remains unpredictable and somewhat elusive, since China has not concluded any new BITs after the China-Tanzania BIT in 2013. China is yet to formulate a coherent and definitive approach in drafting ISDS provisions in newly negotiated or renegotiated BITs in the future. Other problems involve the creation of treaty overlaps and treaty shopping in the Coexistence Model, and the ambiguity of the transition clause in ISDS provisions in BITs in the Replacement Model as demonstrated in Ping An v. Belgium. ${ }^{130}$

\subsection{Promoting Domestic Institutions to Resolve BRI Disputes}

In recent years, Chinese arbitration institutions have adopted new arbitration rules to expand their jurisdiction to admit investor-state disputes. The initiative was taken by the Shenzhen Court of International Arbitration (SCIA) in 2016 through revising its arbitration rules to include investor-state arbitration, ${ }^{131}$ followed by the China International Economic and Trade Arbitration Commission (CIETAC)'s investor-state

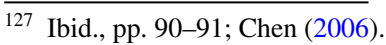

128 Huang (2018).

129 Ibid., pp. 94-95.

130 Ibid., pp. 94-95.

131 SCIA, Arbitration Rules (2016), Art. 2.2, available at: http://120.25.66.138/web/doc/view_rules/939. html (accessed 23 September 2020).
} 
arbitration rules in 2017, ${ }^{132}$ and the Beijing Arbitration Commission (BAC)'s rules for international investment arbitration adopted in 2019. ${ }^{133}$

In addition, two China International Commercial Courts (CICC) under the Supreme People's Court (SPC) have been established in Shenzhen and Xi'an in 2018, which were originally designed to resolve both investor-state and commercial disputes exclusively arising out of the BRI. ${ }^{134}$ Despite the CICC being branded by the media as 'the Belt and Road Courts', ${ }^{135}$ eventually their jurisdiction only covers international commercial disputes between private parties, and is not exclusive to the BRI. ${ }^{136}$ However, this does not exclude the possibility in the future that the CICC will be entrusted with the competence to deal with cases relating to investorstate arbitration, such as the enforcement of ISA awards.

Despite China's ambition demonstrated by recent institutional innovations, some basic issues remain unresolved. First of all, Chinese investors now have the option to resolve their contractual investment disputes by utilizing the CICC or to solve treatybased disputes in three competent Chinese arbitration institutions, hence gaining a 'home advantage' and in the hope of obtaining a favourable outcome. The problems that are inherent in this approach, however, are also apparent. The home advantage that a Chinese disputant wishes to obtain may well be exactly a disadvantage that a foreign disputant wishes to avoid. A foreign disputant, either private or sovereign, will have a compelling rationale to resolve disputes with a Chinese party in a neutral thirdparty venue outside China, rather than doing so in a Chinese institution in China which does not in general convey a strong propensity to impartiality and high-level adjudicative quality. This is the case in particular in view of the fact that China's own level of the rule of law is perceived as relatively weak, as demonstrated by its relatively low ranking in the Rule of Law Index ( $82^{\text {nd }}$ place out of 126 countries). ${ }^{137}$ A substantial improvement in judicial authority and credibility requires consistent and effective endeavour and demonstration in judicial practice, which need to build over time.

Even more problematic is the fact that the mandate of the three Chinese arbitration institutions to hear ISA cases lacks a proper legal basis. China's Arbitration Law, which was last revised in September 2017, explicitly stipulates that only disputes between equal parties, being citizens, legal persons and other organizations, are arbitrable. ${ }^{138}$ Hence, there is an outstanding conflict between China's Arbitration Law and the three Chinese

\footnotetext{
132 CIETAC, International Investment Arbitration Rules (For Trial Implementation) (2017), available at: http://www.cietac.org/index.php?m=Page\&a=index\&id=390\&l=en (accessed 23 September 2020).

133 BAC, Rules for International Investment Arbitration (2019), available at: http://www.bjac. org.cn/page/data_dl/2019\%E6\%8A\%95\%E8\%B5\%84\%E4\%BB\%B2\%E8\%A3\%81\%E8\%A7\%8 4\%E5\%88\%990905\%20\%E8\%8B\%B1\%E6\%96\%87.pdf (accessed 23 September 2020).

134 Chen (2020), p. 102.

135 Jonathan E. Hillman and Matthew P. Goodman, 'China's "Belt and Road" Court to Challenge Current US-Led Order' (Financial Times, 24 July 2018), available at: https://www.ft.com/content/b64d7f2e8f4d-11e8-b639-7680cedcc421 (accessed 23 September 2020).

136 Provisions of the Supreme People's Court of China on Several Issues Regarding the Establishment of the International Commercial Court (Judicial Interpretation of the Supreme People's Court Fa Shi [2018] 11 on 25 June 2018, effective on 1 July 2018), Art. 2.

137 Rule of Law Index 2019, above n. 122.

138 Arbitration Law of China (Promulgated by the National People's Congress on 1 September 2017, effective on 1 January 2018), Art. 2.
} 
arbitration institutions' newly gained competence concerning investor-state disputes. ${ }^{139}$ This may only be solved with a new round of Arbitration Law amendments.

\section{China's Policy Options in ISDS Reform}

\subsection{Investor-State Arbitration with a Standing Appellate Body}

To propose an appeal mechanism in IIAs is anything but an unprecedented practice. One research has found that out of more than 3300 IIAs worldwide, around 25 already contained provisions contemplating an appeal mechanism for investment arbitration. ${ }^{140}$ Out of these 25 IIAs with such a mechanism, the majority proposed the negotiation of a bilateral appellate body first and then a multilateral agreement establishing an appellate body in the future; however, two IIAs, namely the China-Australia FTA (2015) and the Canada-South Korea FTA (2014), contained provisions pertaining to the negotiation of a bilateral appellate body only. ${ }^{141}$ The China-Australia FTA is the first and only attempt in China's IIA-making history to contemplate an appellate body. Article 9.23 of the China-Australia FTA (2015) stipulates that: "Within three years after the date of entry into force of this Agreement, the Parties shall commence negotiations with a view to establishing an appellate mechanism to review awards rendered [...] in arbitrations commenced after any such appellate mechanism is established. Any such appellate mechanism would hear appeals on questions of law.' This attempt, however, has so far not resulted in any substantial outcome.

In July 2019, China submitted its reform proposal to the UNCITRAL WG III. ${ }^{142}$ In China's view, the current ISDS system is flawed with several main problems: a lack of an error-correcting mechanism; a lack of stability and predictability for arbitral awards; the questioned professionalism and independence of arbitrators; unregulated third-party funding; and long and costly procedures. ${ }^{143}$ Consequently, while being 'open to possible proposals for improving the ISDS mechanism', China is inclined to further study the possibility of establishing a permanent appellate mechanism. ${ }^{144}$ This notably suggests the retention of (reformed) investor-state arbitration in combination with an appeal mechanism which could 'help improve error-correcting mechanisms, strengthen legal expectations for investment dispute settlement and establish limitations for the conduct

\footnotetext{
139 Qi (2020), p. 122.

140 Van den Berg (2019), pp. 159-160.

141 Ibid., p. 161.

142 UNCITRAL Working Group III, Possible Reform of Investor-State Dispute Settlement (ISDS): Submission from the Government of China, A/CN.9/WG.III/WP.177 (19 July 2019), available at: https:// undocs.org/en/A/CN.9/WG.III/WP.177 (accessed 23 September 2020).

143 Ibid., pp. 2-3.

144 Other reform proposals that China has made include safeguarding the right of parties to appoint arbitrators; improving arbitrators' qualifications, conflict of interest and their selection and removal procedures; the promotion of alternative dispute resolution measures; a three to six-month compulsory consultation period prior to the commencement of arbitration; and more transparency for third-party funding. Ibid., p. 4.
} 
of judges'. ${ }^{145}$ As identified by Anthea Roberts, ISDS reformers can be placed in three main categories, namely incrementalists, systemic reformers, and paradigm shifters. ${ }^{146}$ China's stance on ISDS reform in the UNCITRAL WG III seems to be in the middle ground between an incrementalist and a systemic reformer: China acknowledges the structural problems of the current ISDS mechanism and prefers to reform the system in ways that are more than merely incremental, such as a permanent and multilateral appellate mechanism; but at the same time it is hesitant to go as far as officially endorsing an MIC as proposed by systemic reformers such as the EU. ${ }^{147}$

\subsection{A Multilateral Instrument Under UNCITRAL Working Group III}

Since 2017 UNCITRAL WG III has been mandated to work on possible ISDS reform. The deliberations of WG III have resulted in various options for ISDS reform being put forward by states. In order to persuade a significant number of states to participate in UNCITRAL ISDS reform, WG III has introduced a 'multilateral instrument' approach, ${ }^{148}$ which intends to provide a framework that integrates various reform options for states to choose to implement. A state could decide to use one or a combination of multiple approaches in their choices. The options provided are as follows:

- A reformed investor-state arbitration;

- A limited reform of certain aspects of ISA, such as a code of conduct, new mechanisms for the selection and appointment of arbitrators, and certain procedures, such as the dismissal of frivolous claims or expedited proceedings;

- A multilateral standing mechanism;

- Only inter-state dispute settlement;

- A mixture of a multilateral standing mechanism, certain elements of such a mechanism, ISA and certain elements of ISA. ${ }^{149}$

All of these ISDS reform proposals as submitted to WG III are competing with each other. As Schill and Vidigal observe, one would be tempted to 'seek multilateral consensus by opening a debate about the pros and cons of each model [...] until a large majority of states are able to agree on one model'; 'yet, it is unlikely that one model ultimately will find such universal support, as the different positions on investment dispute settlement design reflect largely entrenched political stances'

\footnotetext{
145 Ibid.

146 Roberts (2018).

147 Du and Shen (2020), p. 23.

148 UNCITRAL Working Group III, Possible Reform of Investor-State Dispute Settlement (ISDS): Multilateral Instrument on ISDS Reform, Note by the Secretariat, A/CN.9/WG.III/WP194 (16 January 2020), available at: https://uncitral.un.org/sites/uncitral.un.org/files/wp194_multilateral_instrument_for_submi ssion.pdf (accessed 23 September 2020).

149 Ibid., para. 16. Other proposals to reform ISDS have been put forward by international organizations and in academia. Jose E. Alvarez, for instance, classifies them into three groups in reforming the current ISDS regime, from the perspectives of 'rule of law, vertical concerns and horizontal concerns'. Alvarez (2011), pp. 393-406.
} 
with little room for compromise. ${ }^{150}$ Hence, it is of paramount importance to maintain an 'open structure' in ISDS reform in order to garner the widest possible level of state participation, instead of excluding one another. ${ }^{151}$

This multilateral instrument, once materialized, can be employed by China as an available tool to gradually upgrade its BIT regime. Depending on the other contracting party, China may adopt one or more instruments to cater for the stance of the other negotiating state. For instance, the China-India BIT (2006), which included second generation ISDS provisions, was unilaterally terminated by India in 2016, along with another 56 IIAs that India was a contracting party to, due to India's intention to renegotiate its entire BIT regime based on a new Model BIT passed in 2015. ${ }^{152}$ The 2015 Indian Model BIT requires the exhaustion of local remedies before resorting to ISA, whereby an investor must first exhaust all local remedies for a minimum period of five years since the investor first acquired knowledge of a treaty breach, followed by an obligation to use best efforts to resolve the dispute amicably for an additional cooling-off period of six months, prior to the possible commencement of the ISA procedure. ${ }^{153}$ If the renegotiation of the China-India BIT is on the table, China may agree to a limited reform of certain aspects of ISA, namely the strengthening or exhaustion of domestic remedies to resolve investor-state disputes. China and Brazil currently do not have a BIT in place; the dispute resolution mechanism in a future BIT, if at all, would likely include an ombudsman and state-state arbitration instead of ISA, as Brazil has never ratified IIAs containing ISA provisions, ${ }^{154}$ and adamantly advocates so in its submission to the WG III. ${ }^{155}$ Another example is South Africa which in its submission to the WG III proposes a mixture of possible reform instruments. ${ }^{156}$ This means upgrading ISDS provisions in the China-South Africa BIT (1997), which belongs to the second generation of Chinese BITs, would be an open-ended option for both negotiating parties from the inventories of the multilateral instrument.

The use of a multilateral instrument will give China the policy flexibility to conclude new or renegotiate existing BITs with other states in a way that is adaptive of other states' wide range of preferences and engagements in ISDS reform. However, one implication of this approach is that dispute resolution in China's BIT regime will likely be developed to further fragmentation than the status quo: not only are

\footnotetext{
150 Schill and Vidigal (2020), p. 320.

151 Ibid.

152 Agarwal (2019), p. 11.

153 India Model BIT (2015), Art. 15.

154 Vidigal and Stevens (2018), p. 485.

155 UNCITRAL Working Group III, Possible Reform of Investor-State Dispute Settlement (ISDS): Submission from the Government of Brazil, A/CN.9/WG.III/WP.171 (11 June 2019), available at: https:// undocs.org/en/A/CN.9/WG.III/WP.171 (accessed 23 September 2020).

156 They include the use of dispute prevention policies, the use of alternative dispute resolution such as conciliation and mediation, the use of domestic courts and domestic administrative review procedures, setting up an ombuds office, state-state cooperation in dispute prevention, and the banning of, or otherwise more transparent, third-party funding. South Africa was very skeptical about the establishment of a multilateral investment court and an appellate mechanism. UNCITRAL Working Group III, Possible Reform of Investor-State Dispute Settlement (ISDS): Submission from the Government of South Africa, A/CN.9/WG.III/WP.176 (17 July 2019), available at: https://undocs.org/en/A/CN.9/WG.III/WP.176 (accessed 23 September 2020).
} 
there different generations of Chinese BITs already in existence, but also diverse and new approaches to dispute resolution provisions in future BITs negotiated with different contracting states will be adopted.

The EU's proposal for the ICS on the bilateral level is expected to serve a temporary and transitional function and lay the foundation for a permanent $\mathrm{MIC}$ on the international level in the future, as envisaged by the EU. This ultimate objective is endorsed in the EU's submission to UNCITRAL WG III in January 2019 to establish a standing mechanism for the settlement of international investment disputes. ${ }^{157}$ According to the EU, systemic structural reform is the only way that can effectively address all of the major concerns that are raised in current ad hoc arbitration, because incremental reform only addresses certain specific concerns and leaves others untouched. ${ }^{158}$ Therefore, by creating a court-like system with two instances with qualified judges and rule-based transparent proceedings, a standing MIC is going to bring consistency, predictability and correctness of judgements; independence, impartiality, expertise and diversity of adjudicators; and transparency and efficiency of the procedure. ${ }^{159} \mathrm{In}$ order to cover a large amount of existing and future IIAs and to adjudicate disputes arising therefrom, once the instrument establishing the MIC is concluded and open for accession, parties to existing BITs can make an 'opt-in' notification, stating that future disputes arising out of those BITs will be subject to the jurisdiction of the MIC. ${ }^{160}$

It is predicted that the establishment of an MIC needs the support of a minimum of approximately 40 states. ${ }^{161}$ Once the MIC is established, China could make use of the opt-in mechanism to upgrade and unify its current diversified three generations of ISDS provisions, by making joint statements with other contracting states to repeal the ISDS provisions in the current Chinese BIT regime and conferring jurisdiction to the MIC for investor-state disputes arising out of existing Chinese BITs. In this way, ISDS provisions in existing Chinese BITs would be gradually substituted by the MIC through individual bilateral joint statements, instead of a renegotiation of the entire BIT regime which would take much more effort to achieve. For countries that do not yet have a BIT with China, a clear and direct reference to the MIC can be made if a prospective BIT is on the agenda.

\section{Conclusion}

This article explicates the evolving modalities and complexity of ISDS provisions in China's existing three generations of BITs and a fourth generation that is in the making, as well as the necessity and the challenges involved in modernizing and harmonizing these BITs from a Chinese perspective and in the international context of ISDS reform. China's large number of BITs with diversified ISDS provisions and potential ISDS reform options

\footnotetext{
157 European Commission, Submission of the European Union and Its Member States to UNCITRAL Working Group III, Establishing a Standing Mechanism for the Settlement of International Investment Disputes (18 January 2019), available at: http://trade.ec.europa.eu/doclib/docs/2019/january/trado c_157631.pdf (accessed 23 September 2020).

158 Ibid., para. 10.

159 Ibid., paras. 40-56.

160 Ibid., para. 35.

161 Bungenberg and Reinisch (2018), p. 3.
} 
aggravate the 'spaghetti bowl' effect. The ISDS provisions in China's 126 BITs that are currently in force have become so fragmented and diversified, from being rather restrictive to very liberal, all of which co-exist and remain in effect today. This fragmentation presents a dire need for a modernized and unified ISDS mechanism. Although China has already attempted to enhance its existing BITs through a number of ways, some upgrades have created new problems in practice, for instance the ambiguity of the transition clause in ISDS provisions in successive BITs as demonstrated in Ping An v. Belgium.

China's active, if not aggressive, outbound investment in the context of the BRI increases the potential for an extensive use of ISDS in the future. In the course of modernizing its large BIT regime, China faces a dilemma. On the one hand, as the world's second largest capital-importing country, it is in China's defensive interest as a host state to avoid frequent and frivolous claims lodged by foreign investors against China in international arbitration, which implies that ISDS provisions in Chinese BITs should include mechanisms that effectively curb the possibility of frivolous and unmeritorious claims, admit a higher threshold for investors to file claims, and limit the interpretative autonomy of arbitral tribunals to avoid inconsistent outcomes. On the other hand, as the world's largest capital-exporting country, and notably in the context of outbound investment in the BRI, it is also in China's offensive interest as an investors' home state to protect Chinese investors and their investments abroad. This offensive position suggests that ISDS provisions in Chinese BITs should be liberal and in open terms in order to ensure that Chinese investors have as much access as possible to the international settlement of investment disputes.

Considering the fact that to modernize the large number of Chinese BITs on a treaty-by-treaty basis would be an onerous and formidable task, one may deem that it is in China's long-term interest to support the route of an MIC. By utilizing the opt-in mechanism, China would be able to upgrade and replace the fragmented ISDS provisions in the current Chinese BIT regime with the institutional and procedural designs as provided by the MIC that arguably correct many of the structural problems of the current ad hoc arbitration system, without the necessity to renegotiate the entire substantive and procedural provisions of a BIT on a case-by-case basis. Be that as it may, it still remains uncertain if or when China is willing to endorse the establishment of an MIC initiated and advocated by the EU.

Open Access This article is licensed under a Creative Commons Attribution 4.0 International License, which permits use, sharing, adaptation, distribution and reproduction in any medium or format, as long as you give appropriate credit to the original author(s) and the source, provide a link to the Creative Commons licence, and indicate if changes were made. The images or other third party material in this article are included in the article's Creative Commons licence, unless indicated otherwise in a credit line to the material. If material is not included in the article's Creative Commons licence and your intended use is not permitted by statutory regulation or exceeds the permitted use, you will need to obtain permission directly from the copyright holder. To view a copy of this licence, visit http://creativecommons.org/licenses/by/4.0/.

\section{Appendix}

See Tables 2, 3, 4 and 5. 


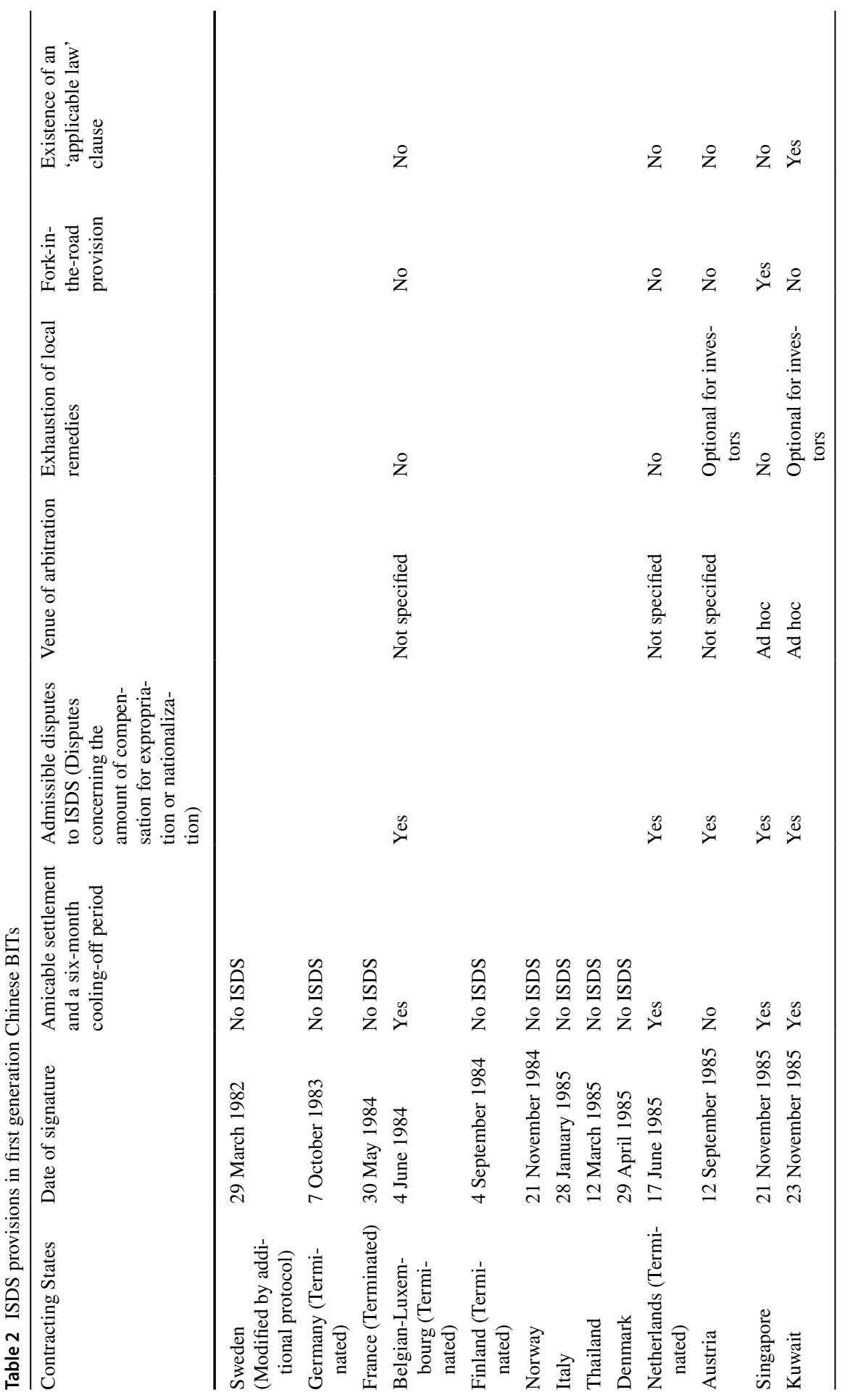




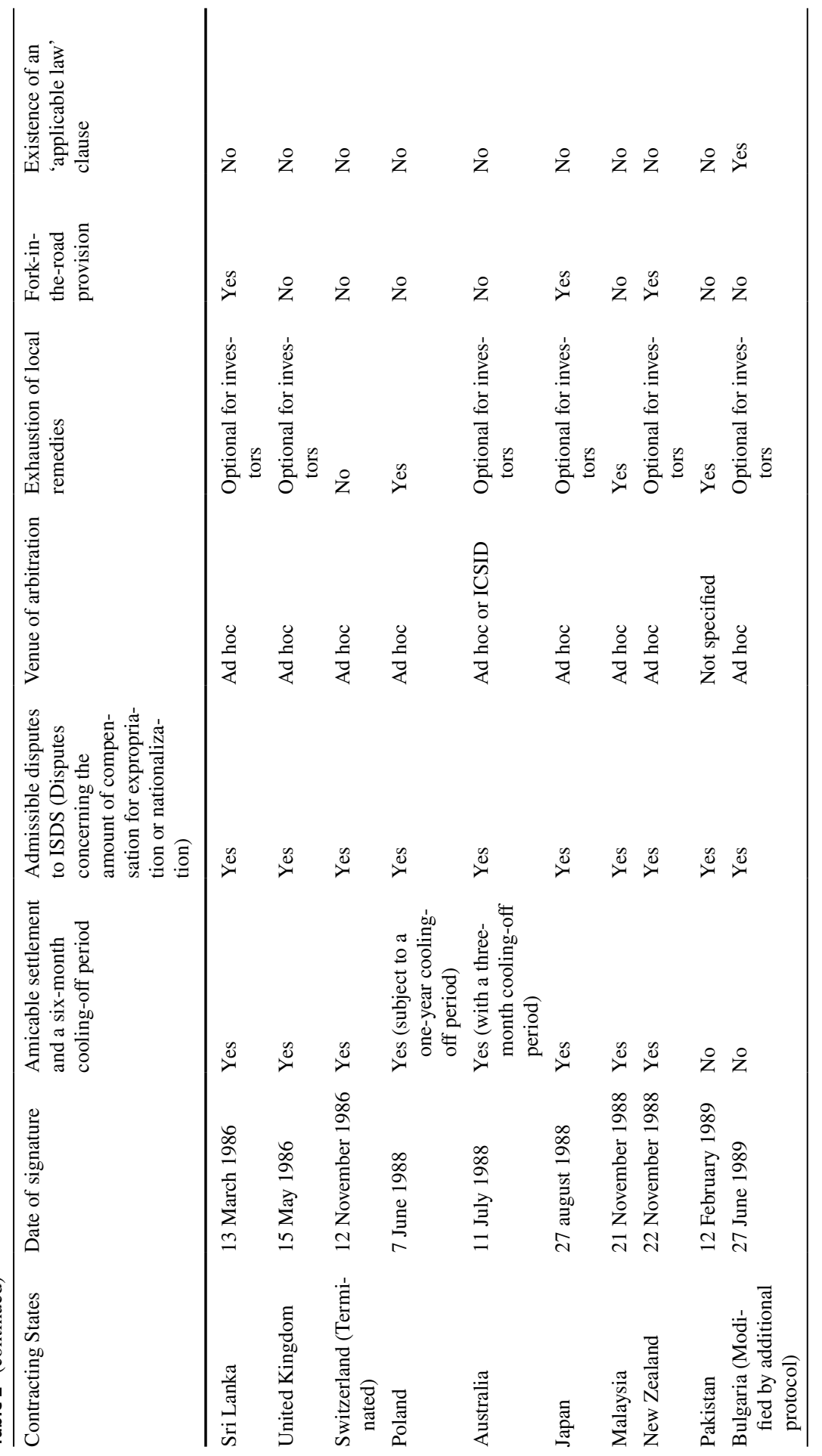




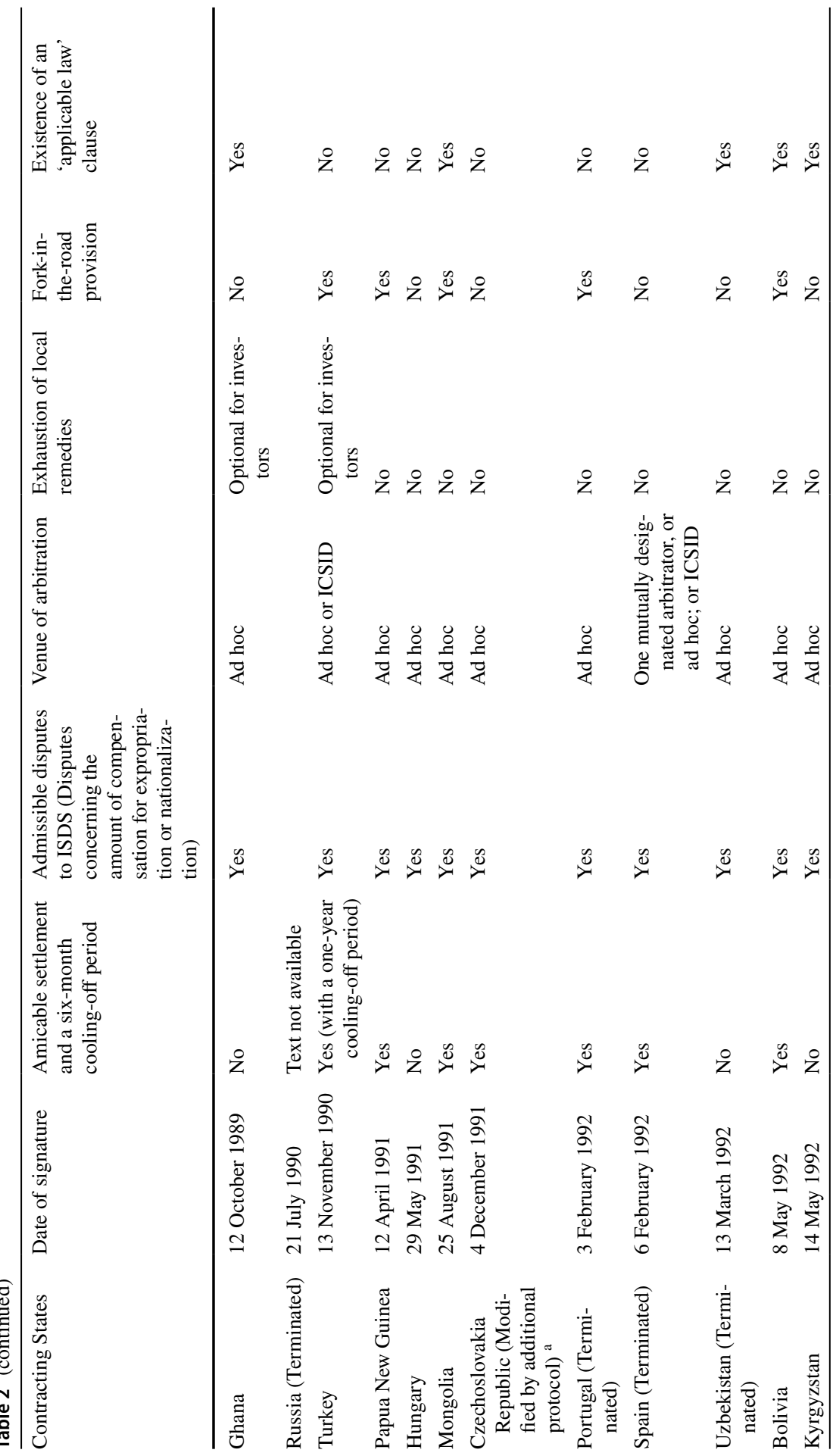




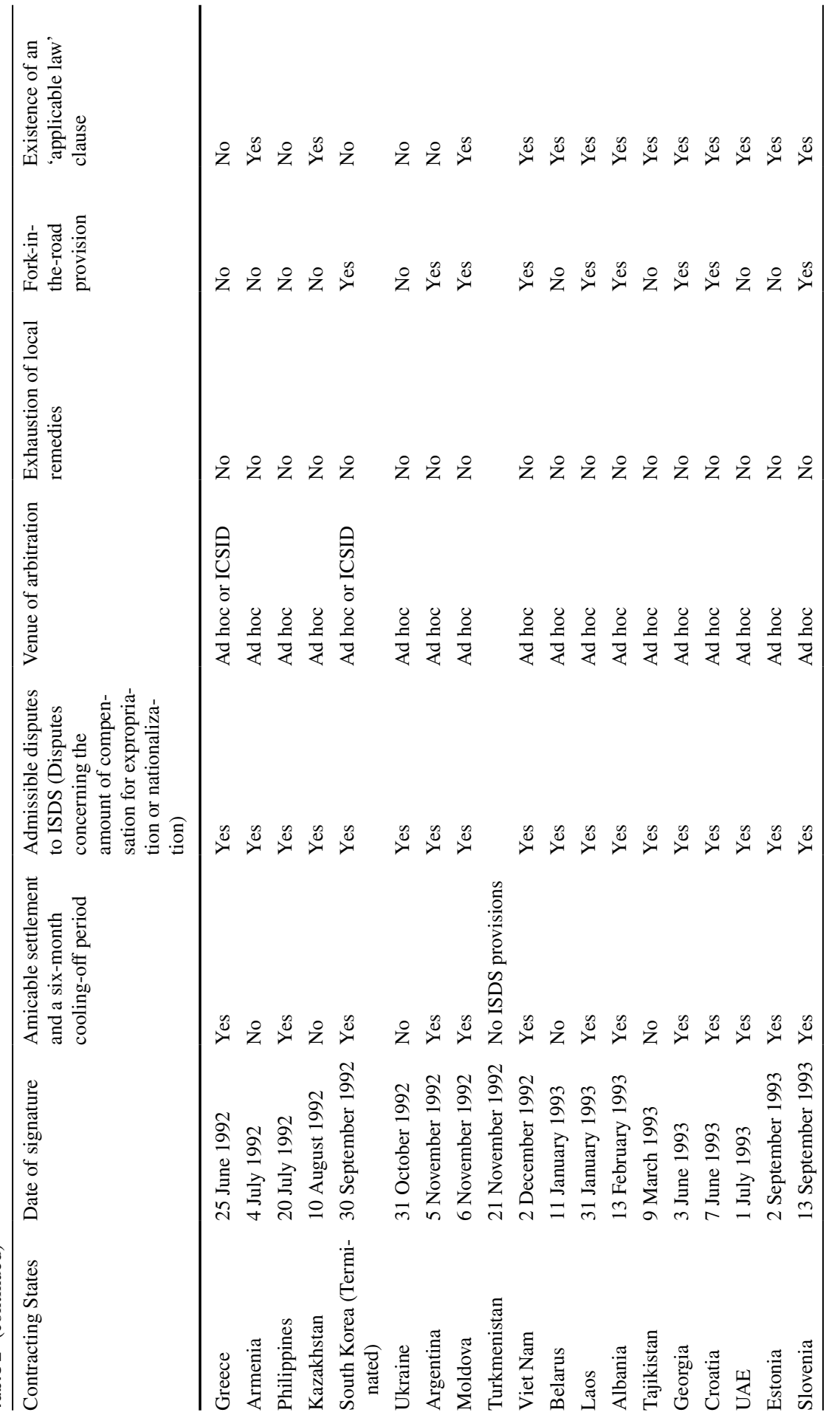




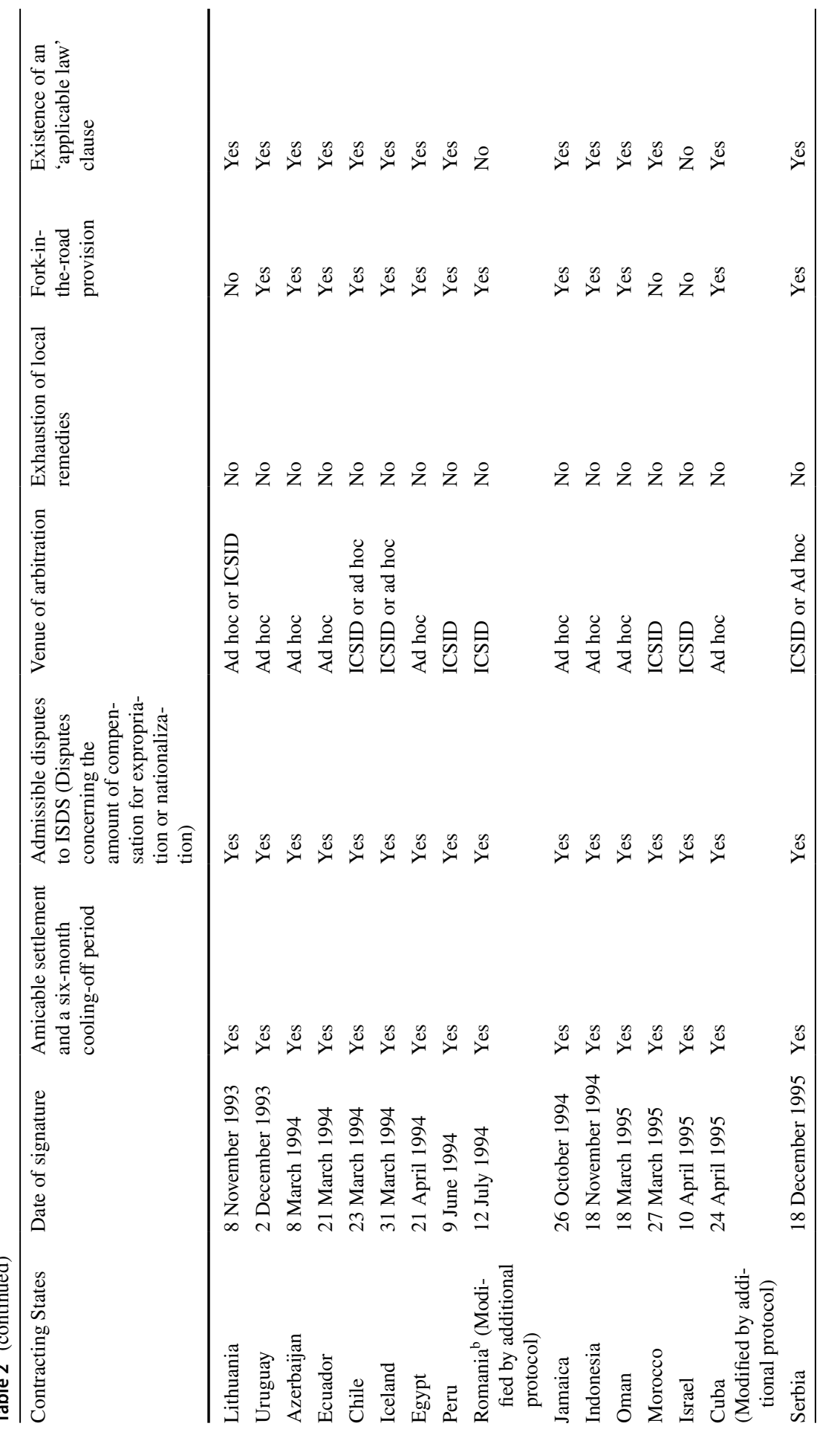




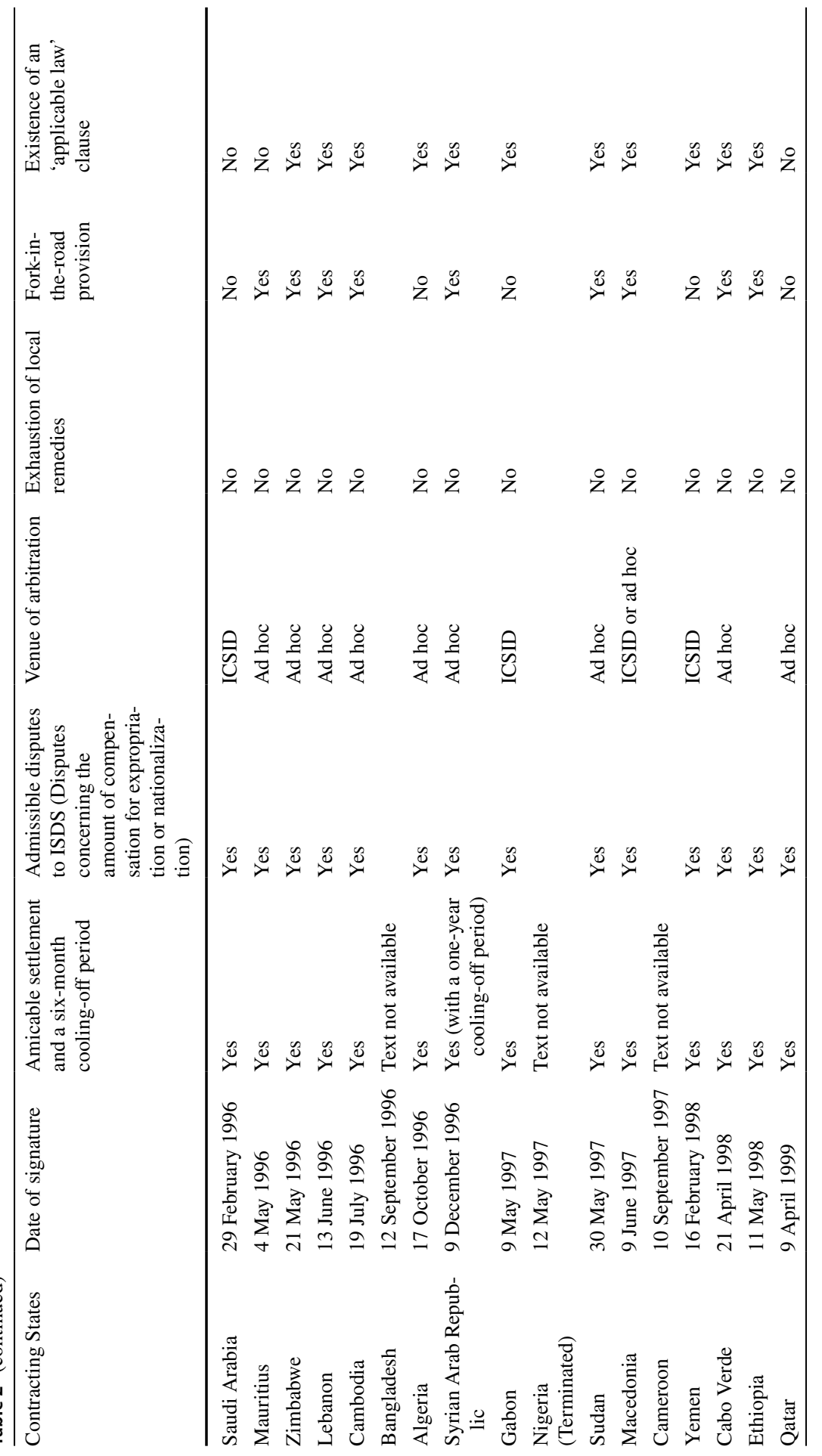




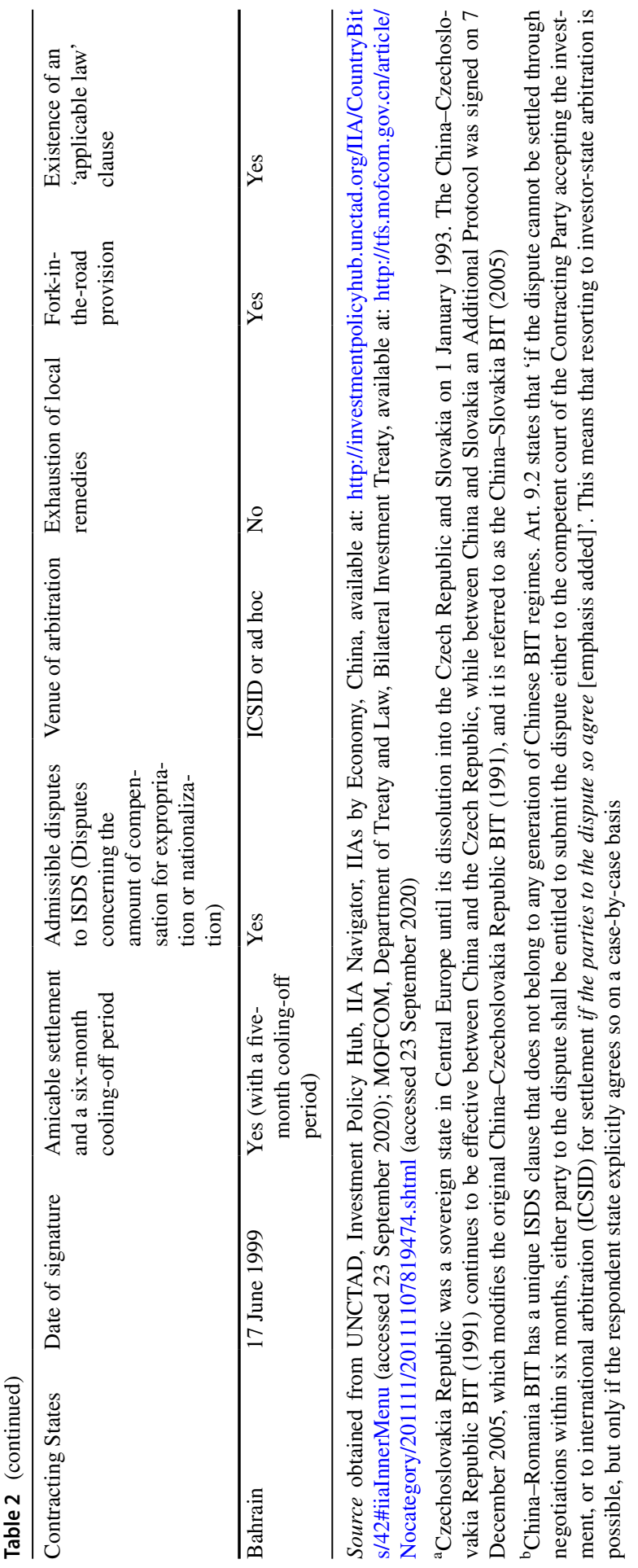




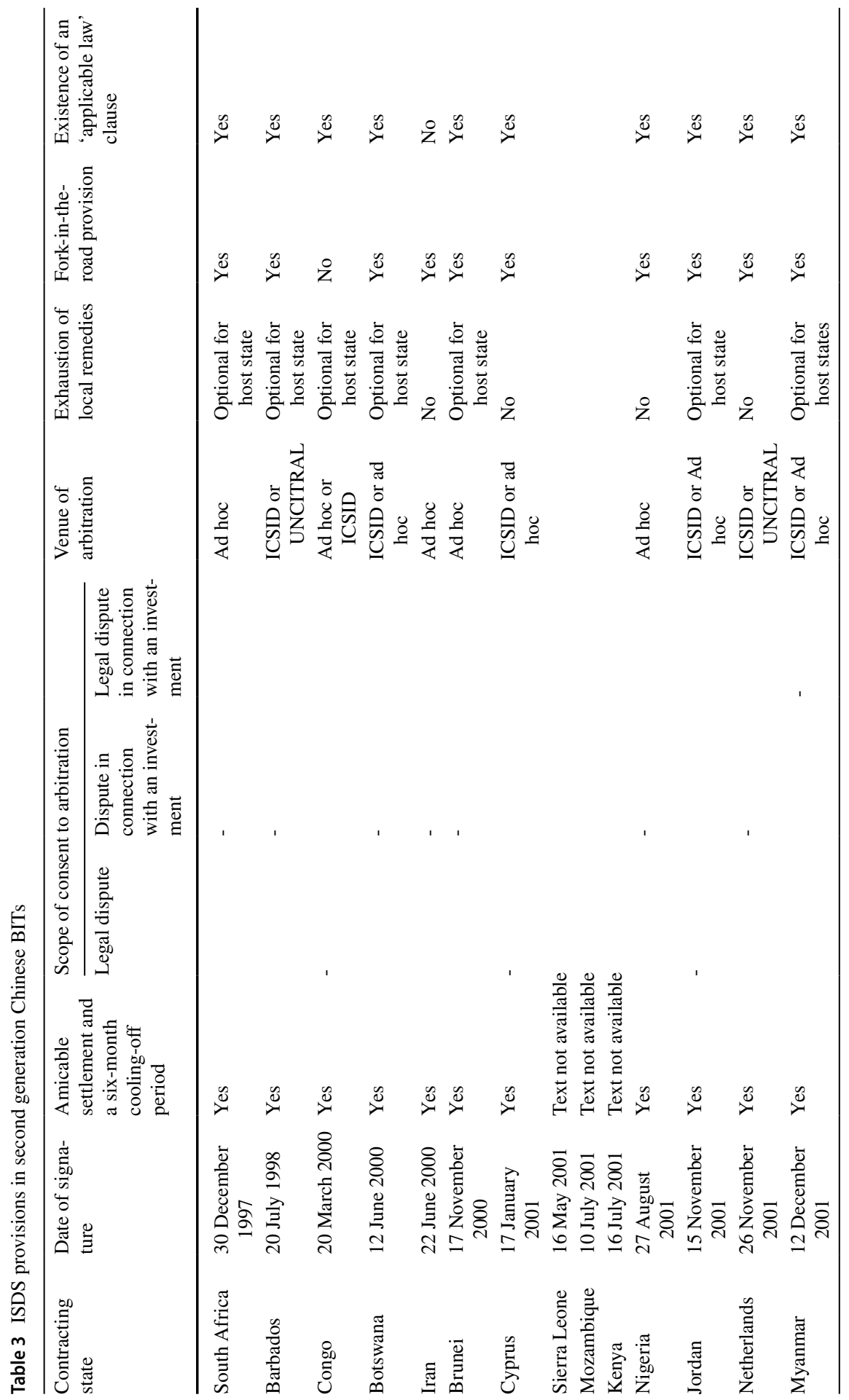




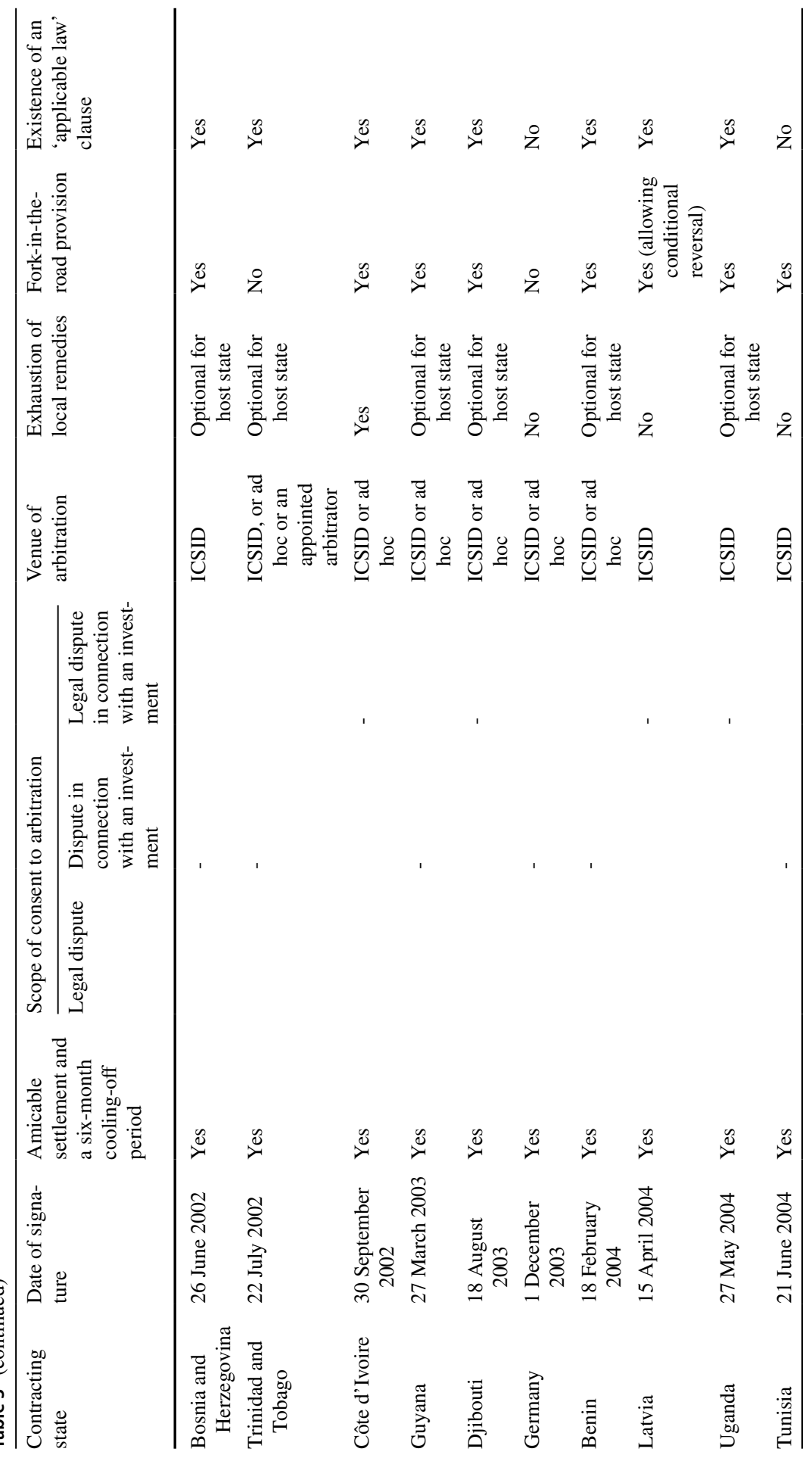




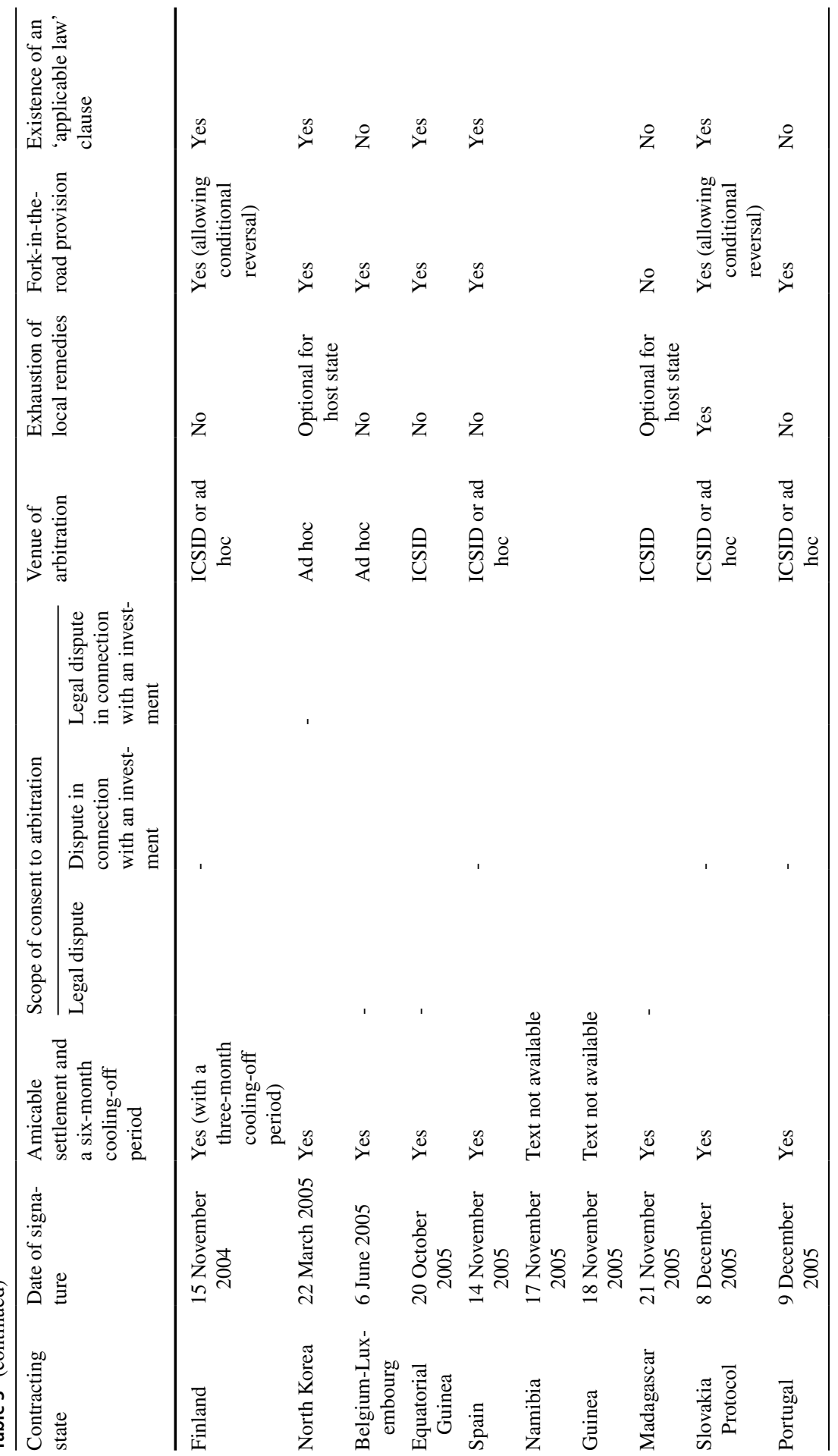




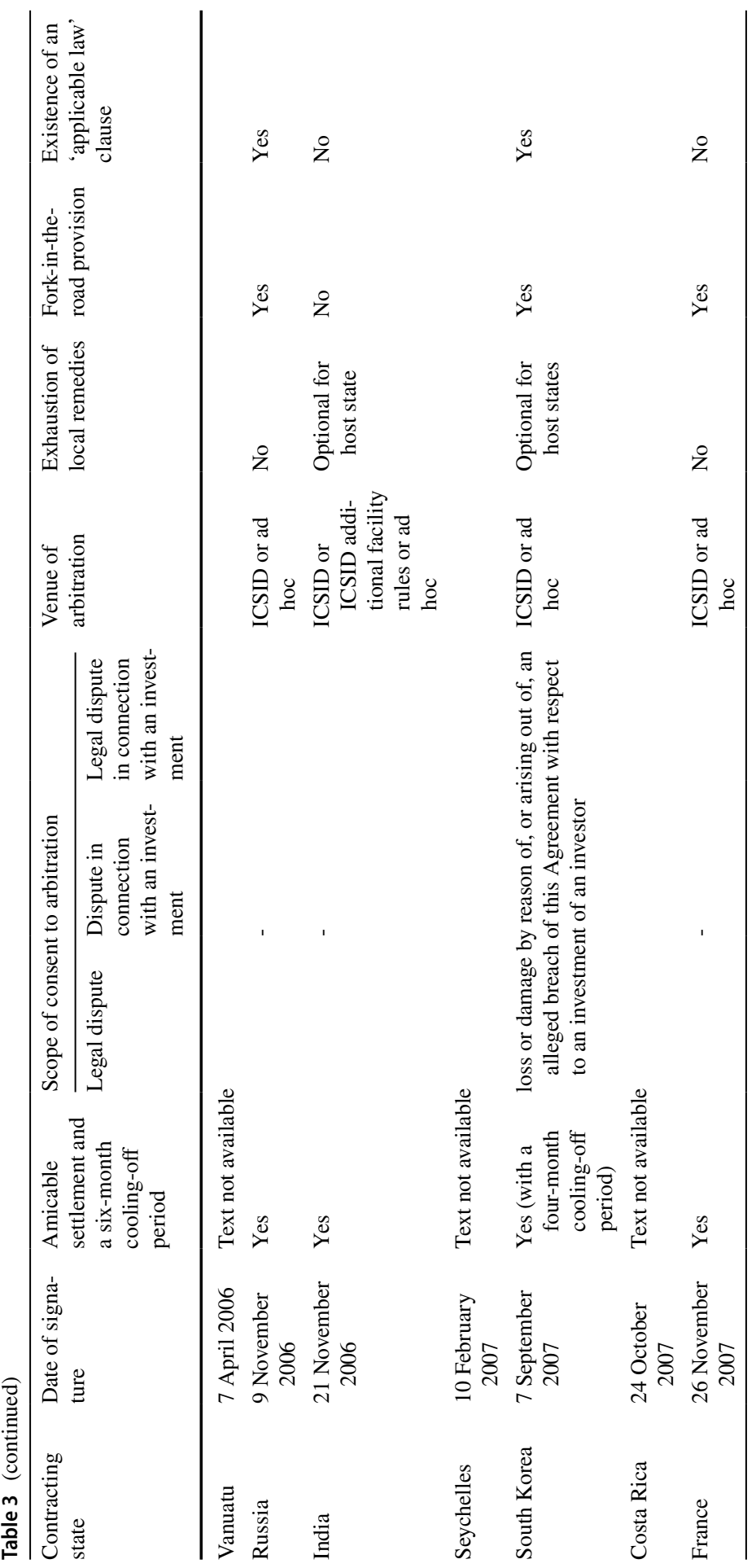




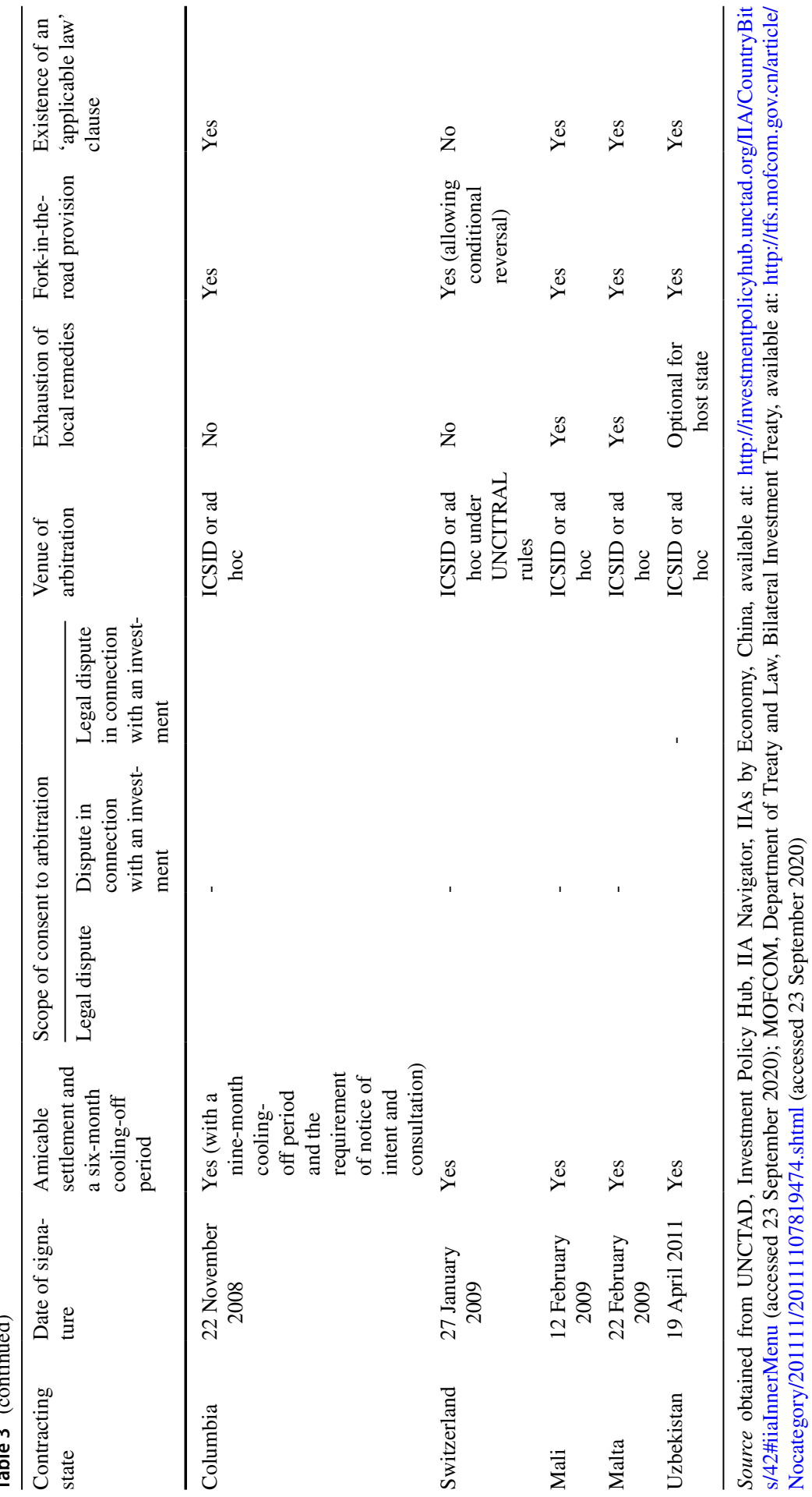




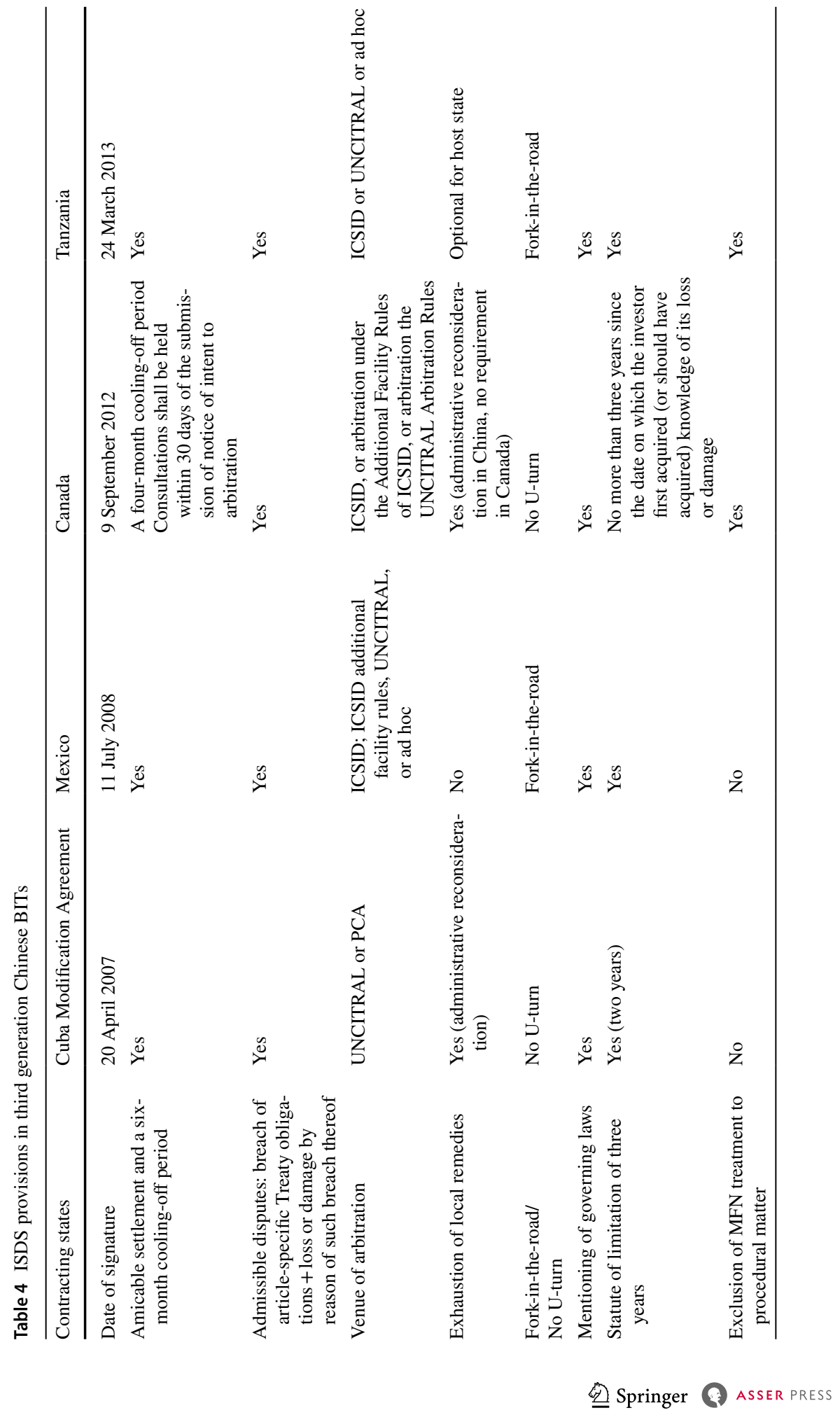




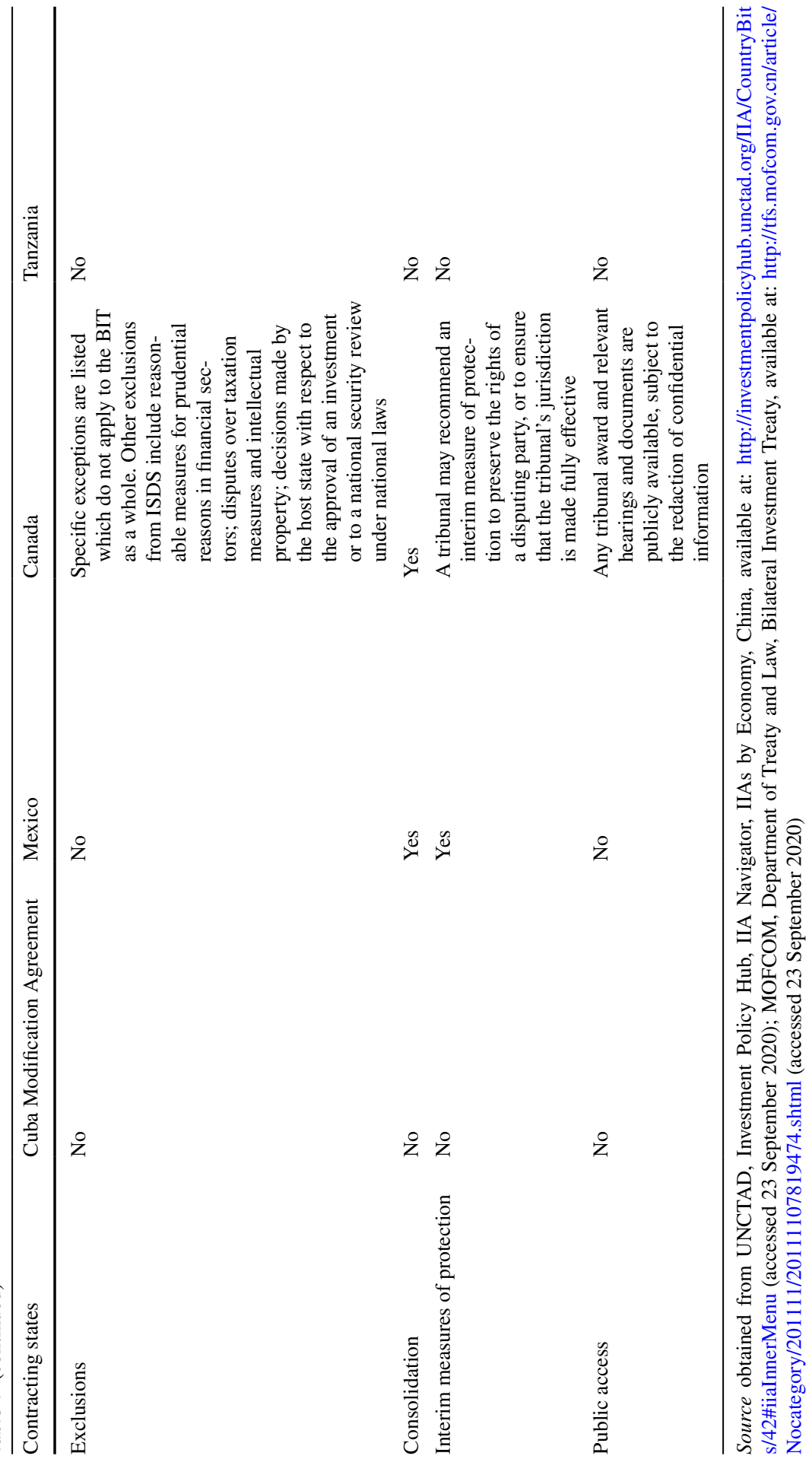




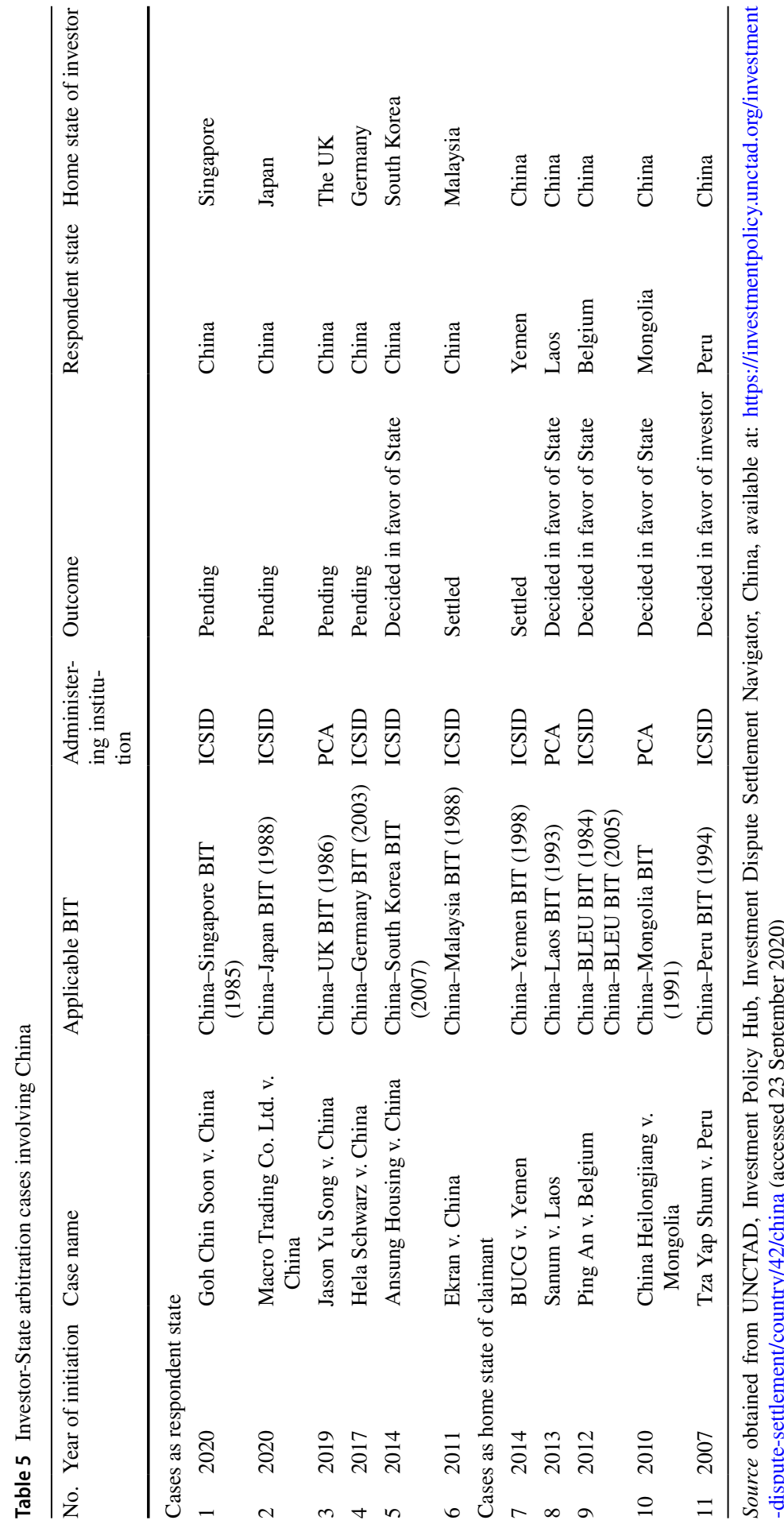




\section{References}

Agarwal A (2019) Rethinking the regulation of international foreign investment: recent developments in Brazil, South Africa and India. Indian J Int Econ Law 10:1-17

Alvarez JE (2011) The public international law regime governing international investment. Brill Nijhoff, The Hague

Amerasinghe CF (2004) Local remedies in international law, 2nd edn. Cambridge University Press, Cambridge

Berger A (2011) The politics of China's investment treaty-making program. In: Broude T, Busch ML, Porges A (eds) The politics of international economic law. Cambridge University Press, Cambridge, pp 162-185

Berger A (2013a) Investment rules in Chinese preferential trade and investment agreements: is China following the global trend towards comprehensive agreements? https://www.die-gdi.de/uploads/ media/DP_7.2013.pdf. Accessed 23 Sept 2020

Berger A (2013) Investment rules in Chinese PTIAs: a partial 'NAFTA-ization' reintegration. In: Hofmann R, Schill S, Tams C (eds) Preferential trade and investment agreements: from recalibration to reintegration. Nomos, Baden-Baden, pp 297-333

Berger A (2015) Hesitant embrace: China's recent approach to international investment rule-making. JWIT 16:843-868

Brauch MD (2017) Exhaustion of local remedies in international investment law. https://www.iisd. $\mathrm{org} / \mathrm{system} /$ files/publications/best-practices-exhaustion-local-remedies-law-investment-en.pdf. Accessed 23 Sept 2020

Bungenberg M, Reinisch A (2018) From bilateral arbitral tribunals and investment courts to a multilateral investment court: options regarding the institutionalization of investor-state dispute settlement. Springer, Berlin

Cai C (2006) Outward foreign direct investment protection and the effectiveness of Chinese BIT practice. JWIT 7:621-652

Cai C (2009) China-US BIT negotiations and the future of investment treaty regime: a grand bilateral bargain with multilateral implications. JIEL 12:457-506

Caplan LM, Sharpe JK (2013) Chapter 18: United States. In: Brown C (ed) Commentaries on selected model investment treaties. Oxford University Press, Oxford, pp 755-851

Carrai MA (2019) China's malleable sovereignty along the Belt and Road Initiative: the case of the 99-year Chinese lease of Hambantota Port. NYU J Int Law Pol 51:1061-1099

Chen A (2006) Should the four great safeguards in Sino-foreign BITs be hastily dismantled? Comments on provisions concerning dispute settlement in model US and Canada BITs. JWIT 7:899-933

Chen H (2020) Reforming ISDS: a Chinese perspective. In: Li Y, Qi T, Bian C (eds) China, the EU and international investment law: reforming investor-state dispute settlement. Routledge, London, pp 100-111

Chi M (2017) From Europeanization toward Americanization: the shift of China's dichotomic investment treaty-making strategy. Can Foreign Policy J 23:158-170

Chi M, Wang X (2015) The evolution of ISA clauses in Chinese IIAs and its practical implications: the admissibility of disputes for investor-state arbitration. JWIT 16:869-898

De Brabandere E, Lemeire S (2017) The jurisdiction ratione temporis of international investment tribunals: some observations on the Decision of the Tribunal in Ping Anv Belgium. https://papers.ssrn. com/sol3/papers.cfm?abstract_id=2994093. Accessed 23 Sept 2020

Douglas Z (2011) The MFN clause in investment arbitration: treaty interpretation off the rails. J Int Dispute Settl 2:97-113

Du M, Shen W (2020) The future of investor-state dispute settlement: exploring China's changing attitude. In: Chaisse J, Choukroune L, Jusoh S (eds) Handbook of international investment law and policy. Springer, Singapore, pp 1-24

Ferdinand P (2016) Westward ho-the China dream and 'One belt, One road': Chinese foreign policy under Xi Jinping. Int Affs 92:941-957

Gallagher N (2016) Role of China in investment: BITs, SOEs, private enterprises, and evolution of policy. ICSID Rev 31:88-103

Hadley K (2013) Do China's BITs matter? Assessing the effect of China's investment agreements on foreign direct investment flows, investors' rights, and the rule of law. Georget J Int Law 45:255-324

Huang J (2018) Procedural models to upgrade BITs: China’s experience. LJIL 31:93-115 
Hwang M, Chang A (2015) Government of the Lao People's Democratic Republic v Sanum Investments Ltd: a tale of two letters. ICSID Rev 30:506-524

Hwang M, Chang A (2018) Of forks and dead ends: Sanum Investments Ltd v Government of the Lao People's Democratic Republic. ICSID Rev 33:156-180

Ji Y (2011) Voluntary 'westernization' of the expropriation rules in Chinese BITs and its implication: an empirical study. JWIT 12:81-99

Lee J (2013) An important first stride, but beware of the pitfalls: a critical analysis of the ISDS mechanism of the 2012 Korea-China-Japan Trilateral Investment Treaty. Chin JIL 12:509-541

Levine M (2019) Towards a fourth generation of Chinese treaty practice: substantive changes, balancing mechanisms, and selective adaption. In: Chaisse J (ed) China's international investment strategy: bilateral, regional, and global law and policy. Oxford University Press, Oxford, pp 205-221

Qi T (2020) China's policy on ISDS reform: institutional choice in a diversified era. In: Li Y, Qi T, Bian $\mathrm{C}$ (eds) China, the EU and international investment law: reforming investor-state dispute settlement. Routledge, London, pp 112-123

Reinisch A (2011) How narrow are narrow dispute settlement clauses in investment treaties? JIDS 2:115-174

Ren Q (2016) Ping An v Belgium: temporal jurisdiction of successive BITs. ICSID Rev 31:129-137

Roberts A (2018) Incremental, systemic, and paradigmatic reform of investor-state arbitration. AJIL 112:410-432

Rooney KM (2007) ICSID and BIT arbitrations and China. J Int Arbitr 24:689-712

Scharaw B (2018) The (provisional) end of debates on narrow dispute settlement clauses in PRC firstgeneration BITs? - China Heilongjiang et al v Mongolia. Arbitr Int 34:293-306

Schill SW (2007) Tearing down the Great Wall: the new generation investment treaties of the People's Republic of China. Cardozo J Int \& Comp Law 15:73-118

Schill SW, Bray HL (2017) The brave new (American) world of international investment law: substantive investment protection standards in mega-regionals. In: Rensmann T (ed) Mega-regional trade agreements. Springer, Cham, pp 123-154

Schill SW, Vidigal G (2020) Designing investment dispute settlement à la carte: insights from comparative institutional design analysis. LAPE 18:314-344

Shan W (2005) The legal framework of EU-China investment relations: a critical appraisal. Hart Publishing, Portland

Shen W (2010) Is this a great leap forward? A comparative review of the investor-state arbitration clause in the ASEAN-China Investment Treaty: from BIT jurisprudential and practical perspectives. J Int Arbitr 27:379-419

Shen W (2011) The good, the bad or the ugly? A critique of the Decision on Jurisdiction and Competence in Tza Yap Shum v. The Republic of Peru. Chin JIL 10:55-95

Titi C (2015) International investment law and the European Union: towards a new generation of international investment agreements. EJIL 26:639-661

Van den Berg AJ (2019) Appeal mechanism for ISDS awards: interaction with the New York and ICSID Conventions. ICSID Rev 34:156-189

Vidigal G, Stevens B (2018) Brazil's new model of dispute settlement for investment: return to the past or alternative for the future? JWIT 19:475-512

Willems JY (2011) The settlement of investor state disputes and China: new developments on ICSID jurisdiction. S C J Int Law Bus 8:1-62

Zhang S (2017) China's approach in drafting the investor-state arbitration clause: a review from the 'Belt and Road' regions' perspective. CJCL 5:79-109

Zhao S (2019) China's Belt-Road Initiative as the signature of President Xi Jinping diplomacy: easier said than done. J Contemp China 28:1-17

Publisher's Note Springer Nature remains neutral with regard to jurisdictional claims in published maps and institutional affiliations. 